BNL 736 (T-265)

(Metals, Ceramics, and Materials - TID-4500, 17th Ed.)

\title{
URANIUM-BISMUTH IN-PILE CORROSION TEST LOOP RADIATION LOOP NO. 1
}

\author{
C.H. Waide, L.E. Kukacka, R.A. Meyer, J. Milau, J.H. Klein, \\ J.G.Y. ChOW, C.J. KLAmut, and D.H. Gurinsky
}

May 1961

BROOKHAVEN NATIONAL LABORATORY UPTON, NEW YORK 


\section{LEGAL NOTICE}

This report was prepared as an account of Government sponsored work Nelther the United States, nor the Commission, nor any person acting on behalf of the Commission

A Makes any warranty or representation, expressed or implied, with respect to the accuracy, completeness, or usefulness of the information contained in this report, or that the use of any information, apparatus, method, or process disclosed in this report may not infringe privately owned rights, or

B Assumes any liabilities with respect to the use of, or for damages resulting from the use of any information, apparatus, method, or process disclosed in this report

As used in the above, "person acting on behalf of the Commıssion" includes any em ployee or contractor of the Commission, or employee of such contractor, to the extent that such employee or contractor of the Commission, or employee of such contractor prepares, disseminates, or provides access to, any information pursuant to his employment or contract with the Commission, or his employment with such contractor

\section{PRINTED IN USA \\ PRICE $\$ 100$}

Avalable from the Office of Technical Services

Department of Commerce

Washington 25, D C 


\section{DISCLAIMER}

This report was prepared as an account of work sponsored by an agency of the United States Government. Neither the United States Government nor any agency Thereof, nor any of their employees, makes any warranty, express or implied, or assumes any legal liability or responsibility for the accuracy, completeness, or usefulness of any information, apparatus, product, or process disclosed, or represents that its use would not infringe privately owned rights. Reference herein to any specific commercial product, process, or service by trade name, trademark, manufacturer, or otherwise does not necessarily constitute or imply its endorsement, recommendation, or favoring by the United States Government or any agency thereof. The views and opinions of authors expressed herein do not necessarily state or reflect those of the United States Government or any agency thereof. 


\section{DISCLAIMER}

Portions of this document may be illegible in electronic image products. Images are produced from the best available original document. 


\begin{abstract}
A loop was operated in the Brookhaven Graphite Research Reactor to determine the effect of in-pile irradiation on the corrosion of various materials by a uranium-bismuth solution. The loop was fabricated of $21 / 4 \%$ chrome $-1 \%$ molybdenum steel and contained, in the in-pile section, specimens of low-chrome steels, carbon steel, molybdenum, beryllium, tantalum, and graphite. The uranium-bismuth solution containing 869 ppm uranium-235, 98 ppm uranium-238, 236 ppm zirconium, and $346 \mathrm{ppm}$ magnesium was circulated at $5 \frac{1 / 4}{\mathrm{gpm}}$. A temperature difference of $75^{\circ} \mathrm{C}$ was maintained on the loop. The in-pile test section ran at $500^{\circ} \mathrm{C}$ and the finned cooler section at $425^{\circ} \mathrm{C}$. The in-pile test section was exposed to a neutron flux of $4.4 \times 10^{12}$ neutrons $/ \mathrm{cm}^{2}$-sec which provided a fission density of $5.5 \times 10^{10}$ fissions $/ \mathrm{cm}^{3}$-sec.

Metallographic examination indicated that the corrosion and/or erosion of the steel and graphite specimens was nil. Wetting of the specimens by the uranium-bismuth solution was limited. Results indicate that in-pile and out-of-pile experimental results are similar and that fission fragment recoils did not contribute materially to either wetting or corrosion under the conditions imposed in this test.
\end{abstract}




\section{CONTENTS}

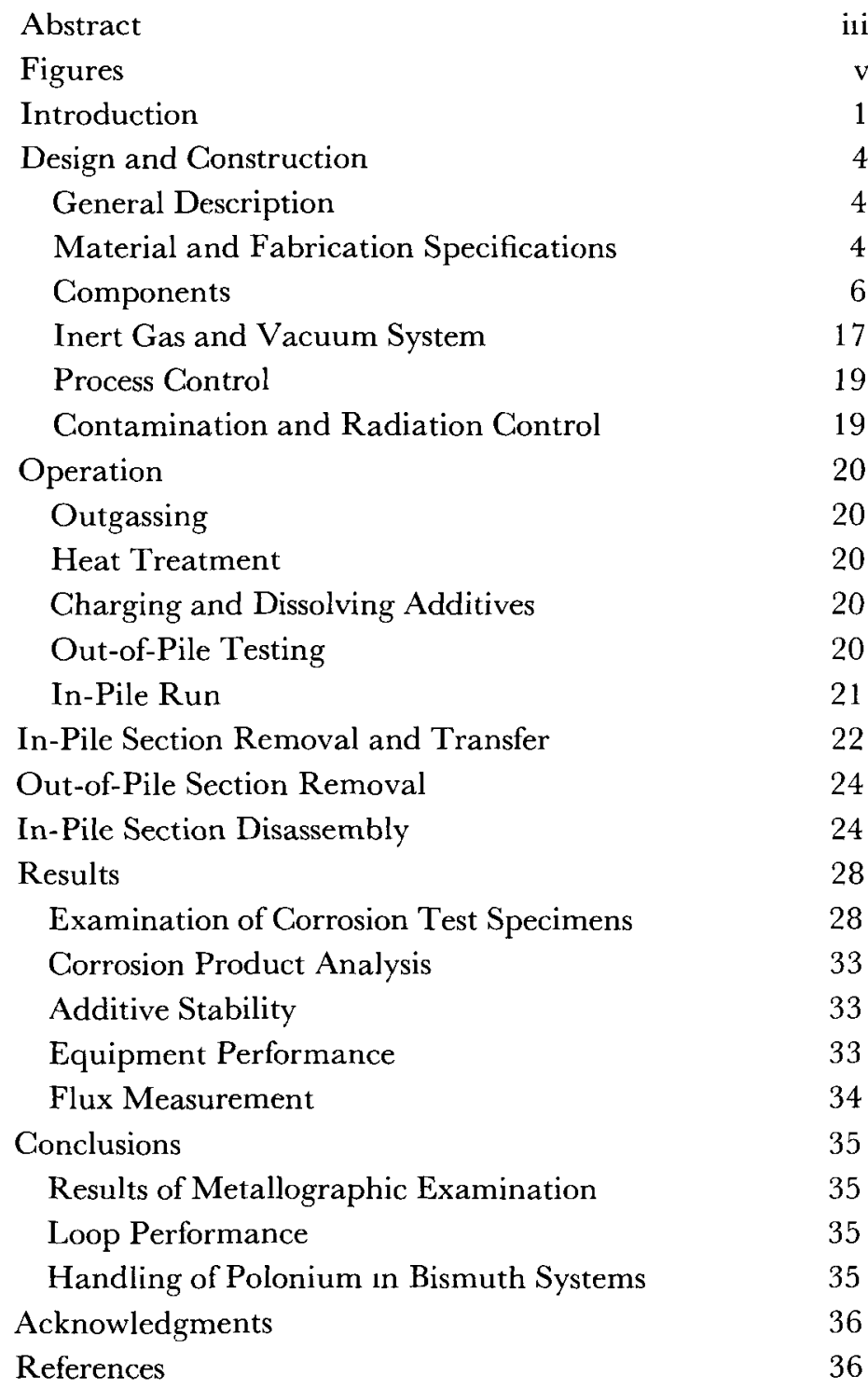




\section{FIGURES}

1. Process flow sheet (drawing) 2

2. Loop assembly (drawing) 3

3. Loop installation (photograph) 5

4. Control panel (photograph) 5

5. In-pile section assembly (drawing) 7

6. In-pile section piping bundle (drawing) 7

7. In-pile section containment shell (drawing)

8. In-pile test section, assembly (drawing) 8

9. In-pile test section, exterior view (photograph) 8

$\begin{array}{lr}\text { 10. In-pile test section, end view (photograph) } & 8\end{array}$

11. In-pile test section, stringer samples (drawing) 8

12. In-pile test section, metal corrosion specimens (drawing) 9

$\begin{array}{lr}\text { 13. Finned cooler (drawing) } & 10\end{array}$

14. Intermediate heat exchanger (drawing) 10

15. Deposition gauge (photograph) 11

16. Deposition gauge circuit (schematic) 11

$\begin{array}{ll}\text { 17. Thermal flowmeter (drawing) } & 13\end{array}$

$\begin{array}{lr}\text { 18. Flowmeter installation (photograph) } & 13\end{array}$

19. Radiation Loop pump (drawing) 14

$\begin{array}{lr}\text { 20. Pump characteristics (graph) } & 15\end{array}$

21. Remote sampler (schematic) 15

22. Remote sampler (photograph) 16

$\begin{array}{ll}\text { 23. Graphite disc drain valve (drawing) } & 17\end{array}$

$\begin{array}{ll}\text { 24. Bellows-sealed valve (drawing) } & 17\end{array}$

25. Process control (schematic) 18

26. In-pile section removal (photograph) 23

27. Pile face area before section removal (photograph) 23

28. Pile face area after section removal (photograph) 23

29. Hot cell and isolation room (drawing) 25

30. Cutoff vise and saw (schematic) 25

31. Vise table (drawing) 26

32. Cutting of in-pile section (photograph) 27

$\begin{array}{ll}\text { 33. Portable hack saw (photograph) } & 27 \\ 34 . & 28\end{array}$

34. Hot cell decontamination (photograph) 28

35. Holdup tank test section (photograph) 29

36. In-pile test section, outer surface (photograph) 29

37. In-pile test section, specimen No. 481 (photograph) 29

38. Graphite and metal stringer samples (photograph) 30

39. Inside surface of test piece No. 478 (photograph) 31

40. Inside surface of transverse weld (photograph) 31

41. Inside surface of deposition gauge (photograph) 31

42. R0020 graphite, slight penetration (microphotograph) 31

43. Graphitite A, heavy penetration (microphotograph) 31

44. Pit, molybdenum stringer sample (microphotograph) 32

45. Pit at surface, specimen No. 484 (microphotograph) 32

46. Shallow pit, specimen No. 483 (microphotograph) 32

47. Heat-affected zone, specimen No. 487 (microphotograph) 33

48. Additive concentrations (graph) 34 


\section{URANIUM-BISMUTH IN-PILE CORROSION TEST LOOP RADIATION LOOP NO. 1}

\section{Introduction}

For several years the Nuclear Engineering Department of Brookhaven National Laboratory was engaged in the study and development of a Liquid Metal Fuel Reactor (LMFR) system. The fuel for this reactor was a $\mathrm{U}-\mathrm{Bi}$ solution to which $\mathrm{Mg}$, an oxygen getter, and $\mathrm{Zr}$, a corrosion inhibitor, were added. The container materials studied were the low-Cr steels, carbon steel, Mo, and Ta. Screening of these materials was accomplished in thermal and forced convection loops. A natural outgrowth of these tests was the need to determine the effect of in-pile irradiation on the corrosion of the various materials in contact with the U-Bi solution. Radiation Loop No. 1 was built to provide this information. Since the data from this loop were to be used in the Liquid Metal Fuel Reactor Experiment (LMFRE) being designed for the Atomic Energy Commission by the Babcock \& Wilcox Co., the loop design and construction became a joint effort between this company and BNL. Brookhaven at all times maintained responsibility for the loop and, with the termination of the LMFR program, completed its construction and operated the loop independently.

The loop was designed to operate under conditions similar to those selected for the LMFRE. Out-of-pile loops were also run under identical conditions in order to isolate the effects due to radiation. The loop was constructed primarily of $2 \frac{1 / 4}{4}$ $\mathrm{Cr}-1 \%$ Mo steel. Materials included in the test sections were $2 \frac{1}{4} \% \mathrm{Cr}-1 \% \mathrm{Mo}$ and $1 \frac{1 / 4}{\mathrm{C}} \mathrm{Cr}-1 / 2 \% \mathrm{Mo}$ steels, carbon steel, $\mathrm{Mo}, \mathrm{Ta}, \mathrm{Be}$, and graphite. A film-to-film temperature difference of $75^{\circ} \mathrm{C}$ was imposed on the loop, with the high temperature $\left(500^{\circ} \mathrm{C}\right)$ end located at the in-pile test section and the low temperature end at the cooler and deposition gauge.

The immediate goals were as follows:

1. To compare the extent of corrosion to that found in out-of-pile loops.
2. To determine the effect of fission recoil particles on $\mathrm{ZrN}$ and $\mathrm{ZrC}$ protective films.

3. To determine the effect of radiation on mass transfer corrosion.

4. To determine additive stability.

5. To determine the extent of Xe, I, and Cs adsorption by graphite.

6. To determine the extent of U-Bi penetration in graphite.

In many cases these goals are interrelated. Information was also obtained with regard to equipment performance and $P_{0}$ contamination and handling.

The loop consisted of an in-pile section in which corrosion specimens were subjected to the circulating $\mathrm{U}-\mathrm{Bi}$ charge in the presence of a neutron flux, a furnace to supplement the nuclear heating and control the test section temperature, a pump, flowmeter, regenerative heat exchanger, deposition gauge, and air-cooled finned cooler. A flow of 5.25 gpm was maintained in the loop, which provided a velocity of $6.1 \mathrm{fps}$ in the test section. The in-pile test section temperature was held at $500^{\circ} \mathrm{C}$ (bulk and inner wall), and the bulk Bi temperature was reduced to $438^{\circ} \mathrm{C}\left(425^{\circ} \mathrm{C}\right.$ inner wall $)$ at the deposition gauge.

The circulating charge consisted of Bi contain-

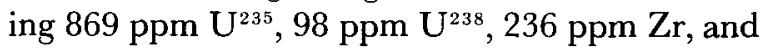
$346 \mathrm{ppm} \mathrm{Mg}$. The $\mathrm{U}$ functioned as the fuel material, the $\mathrm{Mg}$ as an oxygen getter, and the $\mathrm{Zr}$ as a corrosion inhibitor.

The Bi stream in the in-pile test section was exposed to a measured flux of $4.4 \times 10^{12}$ neutrons/ $\mathrm{cm}^{2}$-sec, which corresponds to a fission density of $5.5 \times 10^{10}$ fissions $/ \mathrm{cm}^{3}$-sec.

The loop operated in the reactor for $3409 \mathrm{hr}$, of which $3048 \mathrm{hr}$ were at the design conditions of flow, temperature gradient, and flux. In-pile operation started on April 2, 1960. The additive concentrations and shielding tests were completed and the final run started on June 9, 1960. On November 17,1960 , the 3000 -hr run was completed. 


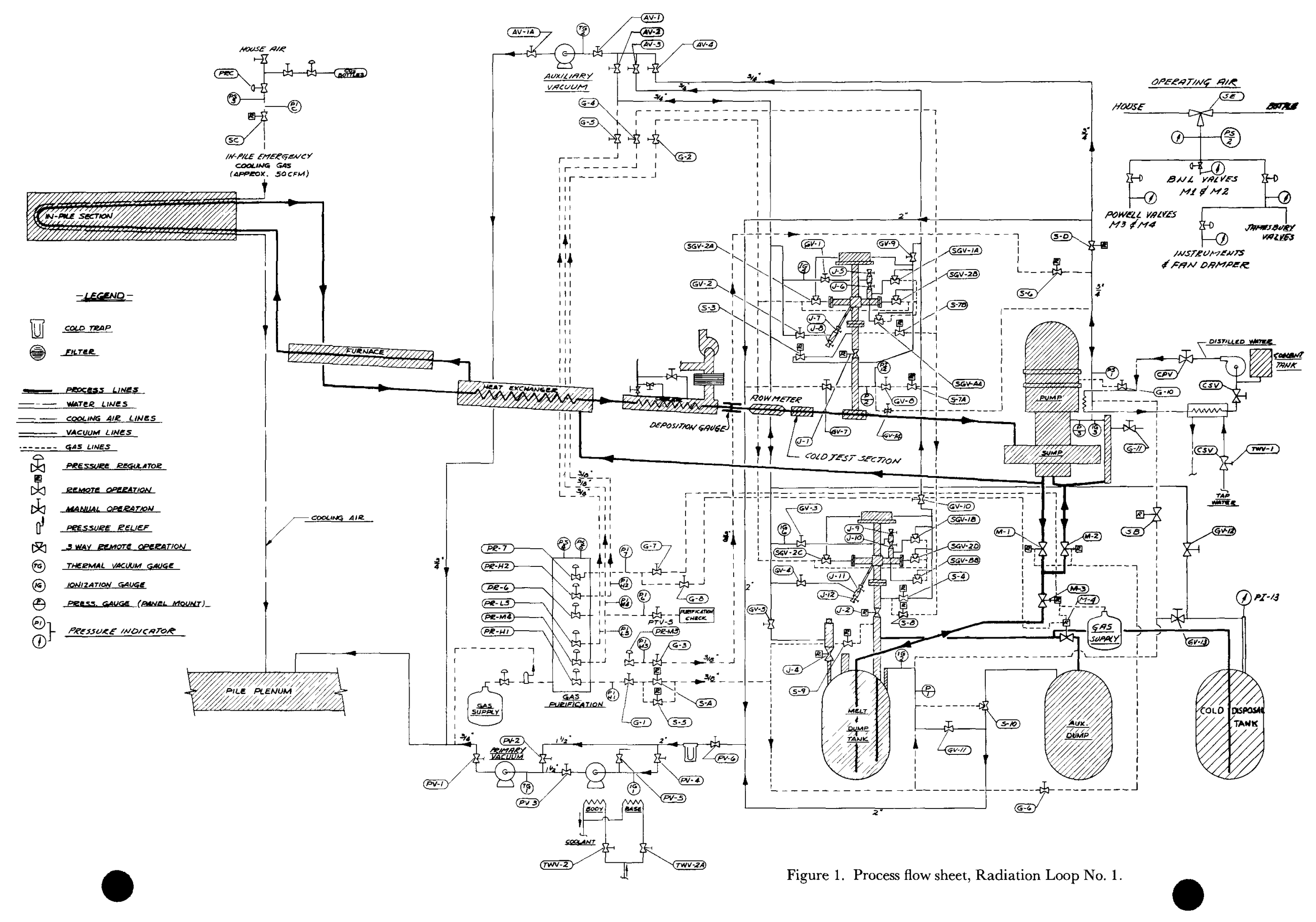




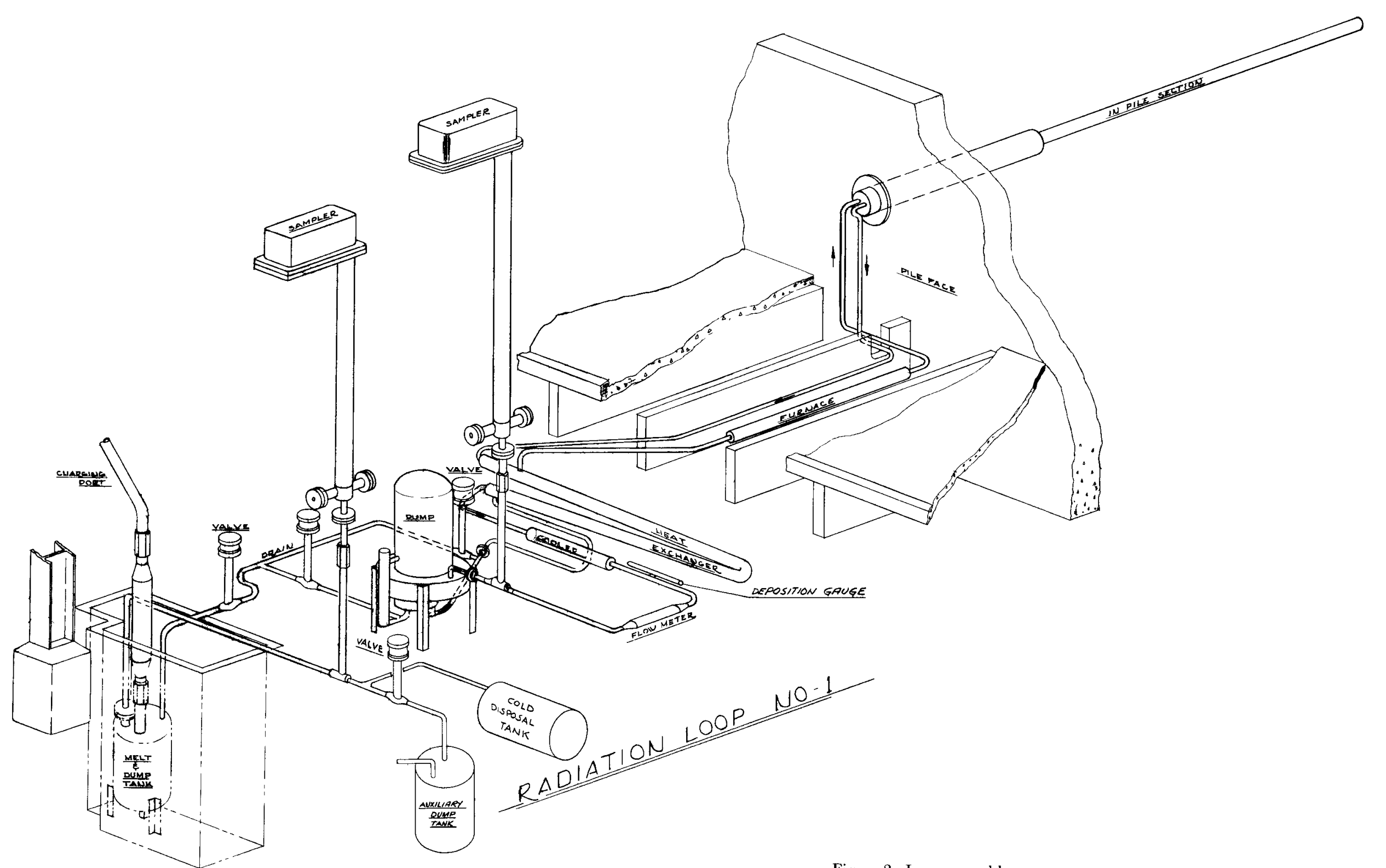

Figure 2. Loop assembly. 


\section{Design and Construction}

\section{GENERAL DESCRIPTION}

A process flow diagram of the loop is shown in Figure 1, and an isometric view is given in Figure 2. The loop was a figure-of-eight type with a furnace and in-pile section in one half, and a cooler, deposition gauge, pump, sampler, and flowmeter in the other half. The two halves of the loop were joined by a shell-and-tube heat exchanger in which fluid from the in-pile section entered the tube side and was returned through the shell side.

In operation, the U-Bi charge, circulating at a flow rate of $5.25 \mathrm{gpm}$, was heated to the upper operating temperature $\left(500^{\circ} \mathrm{C}\right.$ bulk and inner skin) by the furnace and by nuclear heating in the in-pile section. In the intermediate heat exchanger some of the heat was transferred to the cool $\mathrm{Bi}$ entering the furnace. The $\mathrm{Bi}$ was then cooled to the lower operating temperature $\left(438^{\circ} \mathrm{C}\right.$ bulk, $425^{\circ} \mathrm{C}$ inner skin) by the air-cooled finned cooler and the deposition gauge. The charge then passed through the flowmeter, sampler, and pump and was returned to the heat exchanger.

Charging, flushing, and disposal of the Bi was accomplished with a system of three dump tanks: a melt and dump tank used during routine startups and shutdowns and for sampling, an auxiliary dump tank to dispose of the active charge, and a disposal tank to remove the out-of-pile run charge and to prepare and store the flushing run charge.

The loop was constructed of $2 \frac{1 / 4}{4} \mathrm{Cr}-1 \%$ Mo steel. All piping runs were of $3 / 4$-in. Sch. 40 pipe. Two corrosion test sections were installed in the in-pile section of the loop, one located in the tip, where both temperature and neutron flux were at a maximum, and the other in a region of low flux and high temperature. The materials used in the test sections are described in detail in a later section of the report.

Equipment developed specifically for use in this loop included a remote sampler incorporating the thief-sampling principle used on out-of-pile loops, a valve utilizing a graphite-faced piston which seated against a metal seat, a thermal balance flowmeter, and a deposition gauge to monitor the build-up of corrosion products in the low temperature part of the loop. These and the other loop components are described in other sections of the report.
Because of reactivity with air, the molten fuel solution had to be blanketed with inert gas at all times. Purified Ar was used during out-of-pile tests, and $\mathrm{He}$ was used for all in-pile work. Because the circulating fluid contained enriched U, Po, and fission products, the entire loop was contained in an enclosure maintained below atmospheric pressure and was surrounded by a 2 -ft-thick heavy concrete shield.

Since operation with $\mathrm{Bi}$ required that all lines be above the minimum operating temperature before the loop was filled, all the piping was wrapped with armor-clad flexible nichrome heater wire and insulated. Thermocouples tack-welded to the piping or installed in wells were used to monitor the loop temperatures.

Figures 3 and 4 show, respectively, the loop installation before shielding and the loop control panel.

The construction of the loop was a joint effort by Brookhaven National Laboratory and the Babcock \& Wilcox Co. Several of the out-of-pile components were fabricated by B \&W. Engineering and construction assistance was made available to $\mathrm{BNL}$ for most of the construction period.

\section{MATERIAL AND FABRICATION SPECIFICATIONS}

\section{Material of Construction}

The loop was fabricated from two heats of $2 \frac{1}{4} \%$ $\mathrm{Cr}-1 \%$ Mo steel having the analyses shown in Table 1. All piping up to 2 in. IPS was subjected to both hydrostatic and ultrasonic tests. Sizes beyond this received a hydrostatic test. The piping used for the in-pile section was radiographed as well.

Table 1

Loop Material Analysis

\begin{tabular}{|c|c|c|}
\hline \multirow[b]{2}{*}{$\begin{array}{l}\text { Per cent analysis } \\
\text { of loop material }\end{array}$} & \multicolumn{2}{|c|}{ Material Heat No. } \\
\hline & $\begin{array}{l}\text { Pipe, tubing, } \\
\text { and bar stock, } \\
\text { B\&W Heat } \\
\text { No. } 44459\end{array}$ & $\begin{array}{c}\text { Plate, Lukens } \\
\text { Heat No. } 56663\end{array}$ \\
\hline $\mathrm{Cr}$ & 2.3 & 2.50 \\
\hline Mo & 1.03 & 0.96 \\
\hline $\mathrm{C}$ & 0.11 & 0.07 \\
\hline $\mathrm{Mn}$ & 0.46 & 0.47 \\
\hline $\mathbf{S}$ & 0.016 & 0.030 \\
\hline $\mathrm{P}$ & 0.016 & 0.012 \\
\hline $\mathrm{Si}$ & 0.37 & 0.29 \\
\hline $\mathrm{Al}$ & - & 0.024 \\
\hline
\end{tabular}




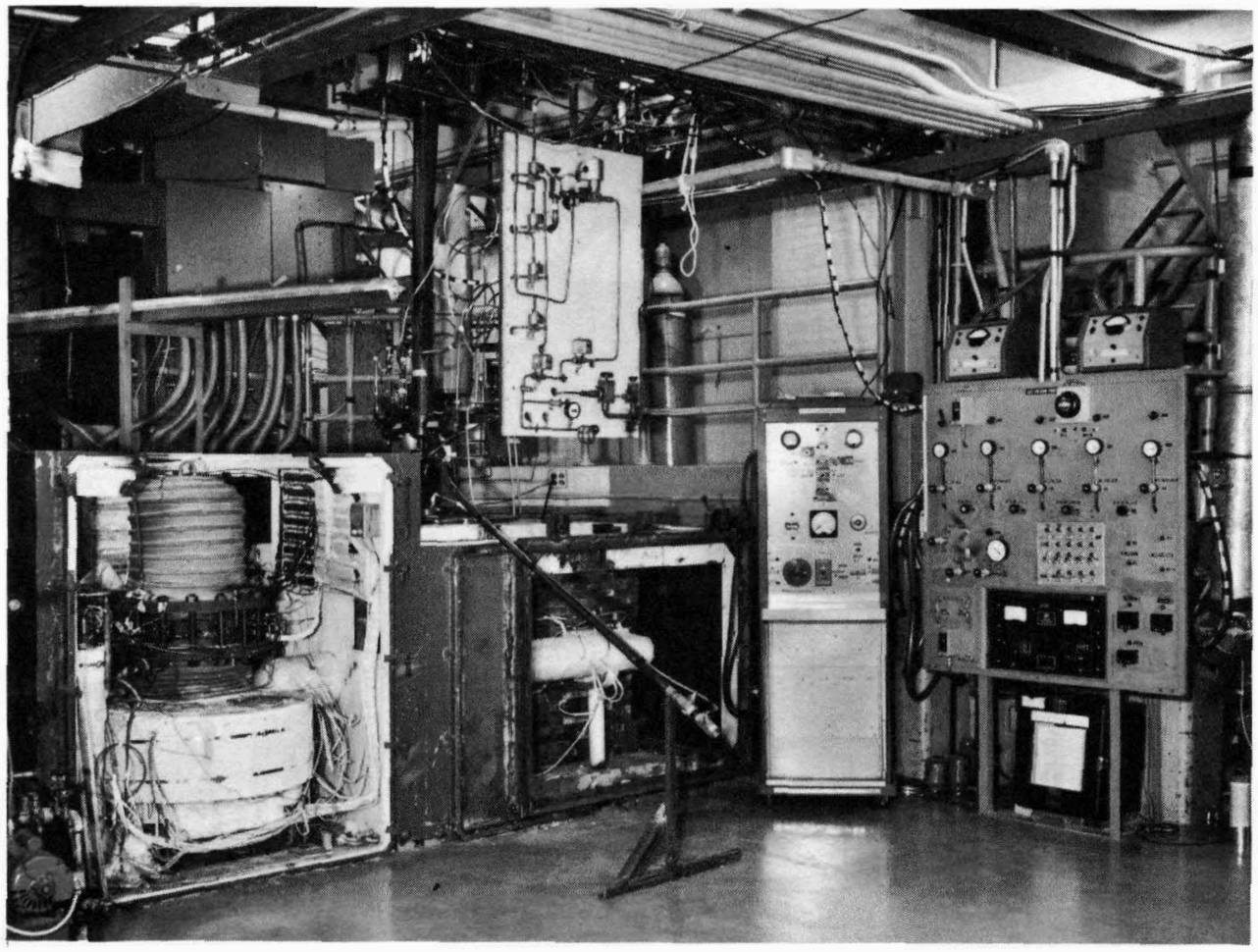

Figure 3. Loop installation during out-of-pile test.

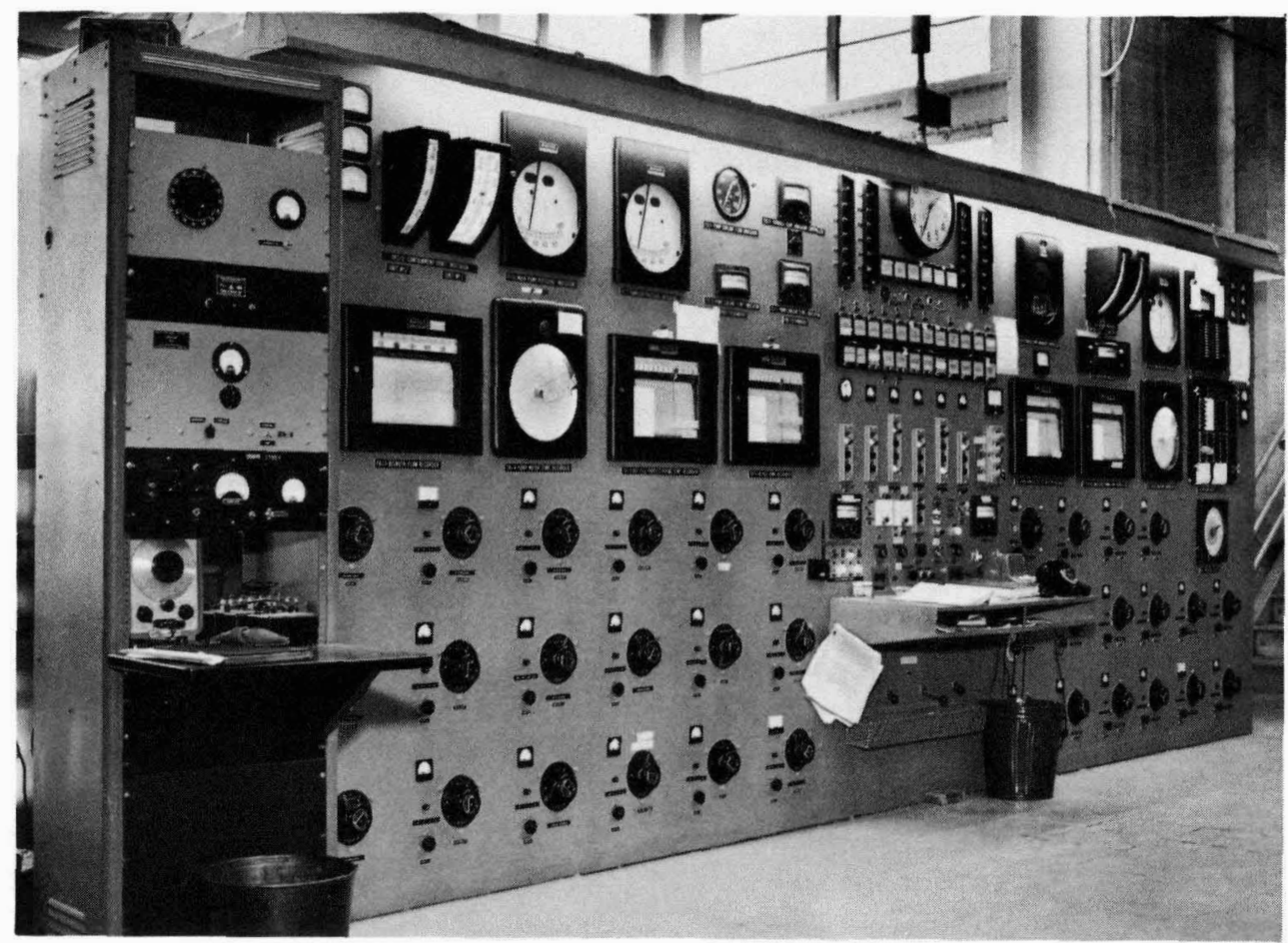

Figure 4. Control panel. 


\section{Welding Rod}

Arcos type 521 bare rod without $\mathrm{Cu}$ or $\mathrm{Al}$ coating was used for all inert-gas-shielded tungstenarc-process welding. This method was also used for the first pass on heavy wall pipe or vessels. Murex Croloy 21/4A or Champion Croloy 21/4A was used for metallic arc welding after the first pass on heavy wall pipe or vessels. In all cases the rods were selected so that the atom ratio of total nitrogen to acid-soluble $\mathrm{Al}$ was $>1$.

\section{Fabrication}

Cleaning. All surfaces exposed to the process fluid were cleaned by degreasing with hot trichloroethylene vapor and/or liquid. Mill scale and oxide were then removed by silica sandblasting, which left a clean metal surface free of discoloration. Brushing and vacuuming removed residual sand after this operation. The cleanliness of the equipment was then maintained by blanketing the exposed surfaces with an inert gas atmosphere, usually Ar.

Welding. Full penetration welds were used throughout the loop to eliminate crevices into which the Bi could penetrate. All initial passes were made by using the inert-gas-shielded tungstenarc process. Subsequent passes were made by using this process or, on heavy-walled equipment, the manual metallic-arc process. Ar of $99.8 \%$ minimum purity was used as shielding gas and for the blanket gas inside the pipe. The use of $\mathrm{He}$ was avoided because of its interference in later leak-testing procedures. Only welders who met qualification requirements established by BNL were employed in fabricating the loop.

All welds were stress-relieved at $719^{\circ} \pm 14^{\circ} \mathrm{C}$ for a period of $1 \mathrm{hr}$. The welds produced in $\mathrm{B} \& \mathrm{~W}$ shops were stress-relieved during fabrication, and those produced at BNL were stress-relieved during the outgassing phase of the operation. This procedure is described later.

Each weld was radiographed by using either $x$ rays or gamma rays. Only welds showing full penetration, no porosity, no excessive dropthrough, or other defects were acceptable.

Testing. Hydrostatic tests on the piping and vessels were performed wherever feasible. Subassemblies and the entire loop, including both process, gas, and vacuum piping, were He massspectrometer leak-tested by the following techniques: The components to be tested were evacu- ated through a pumping system to which a $\mathrm{He}$ mass-spectrometer leak detector was connected. The detector was rated to detect leaks as small as $10^{-9}$ atmospheric cc/sec. An initial test was made by probing the exterior of the component with a He gas probe. Any detectable leaks were repaired. Final testing was accomplished by surrounding the component with a plastic envelope into which $\mathrm{He}$ was introduced. Any leakage detected at this stage was pin-pointed by bagging and testing parts of the component until the leak was isolated.

This method, including the bagging, was used on the entire loop assembly, and for the final leak test it was possible to maintain the vacuum in the loop by using only the leak detector vacuum system. Under these conditions no leakage was detected. The leak detector was checked against a standard leak before each major test period. The leak test was repeated with the loop at $260^{\circ}$ and $538^{\circ} \mathrm{C}$.

\section{COMPONENTS}

\section{In-Pile Section}

The in-pile section assembly, shown in Figure 5, is composed of two parts, an inner piping bundle containing the circulating Bi stream, and a containment and insulating shell.

The in-pile piping bundle consisted of an inner bayonet unit that was inserted into the pile graphite, and a holdup tank located in the pile shield region. Figure 6 is an over-all view of the bundle. The bayonet unit was $13 \mathrm{ft}, 23 / 4 \mathrm{in}$. long and consisted of a concentric pipe bayonet in which the fuel flowed through an annulus between the 1-in. Sch. 40 outer pipe and the $1 / 2$-in. Sch. 40 inner pipe to the tip and returned through the inner pipe. The inner pipe was positioned by sets of three spacers $120^{\circ}$ apart, placed at 12 -in. intervals along the pipe. A piece of HLM type graphite was located inside the tip of the outer pipe. A test section, described in the following section, was located at the tip of the inner pipe where the neutron flux and temperature were highest.

During the initial start-up and whenever the reactor was not operating, the in-pile section was heated by three calrod heaters, one rated at 2200 $\mathrm{w}$ at $220 \mathrm{v}$, and two others rated at $1100 \mathrm{w}$ at $220 \mathrm{v}$.

To provide emergency cooling of the piping bundle if a plug or leak should make it necessary to remove the fission heat, or in the event of a temperature excursion, six $3 / 8$-in. carbon steel tubes 


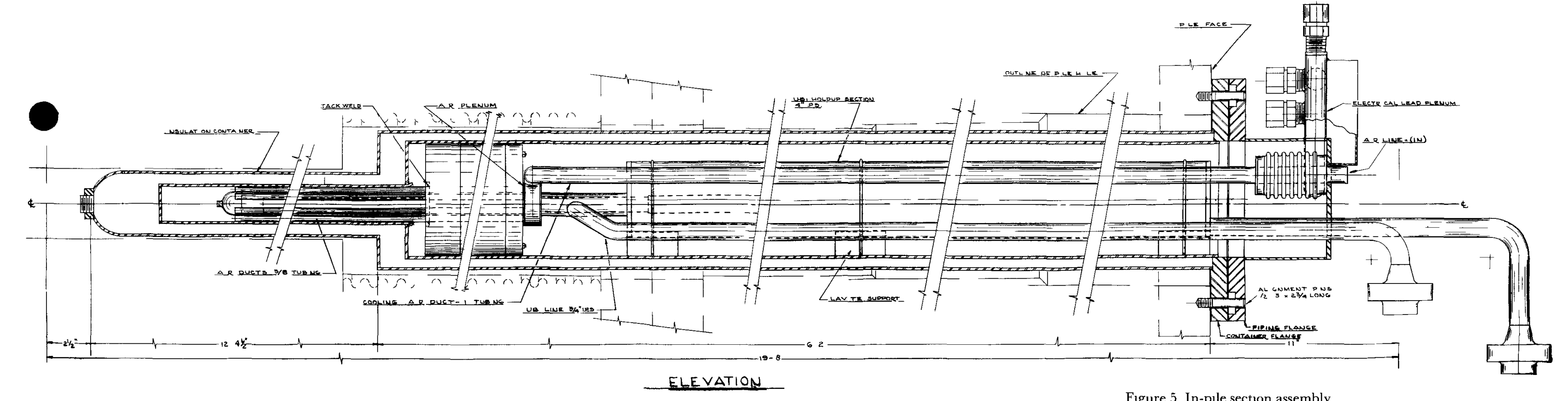

Figure 5 In-ple section assembly

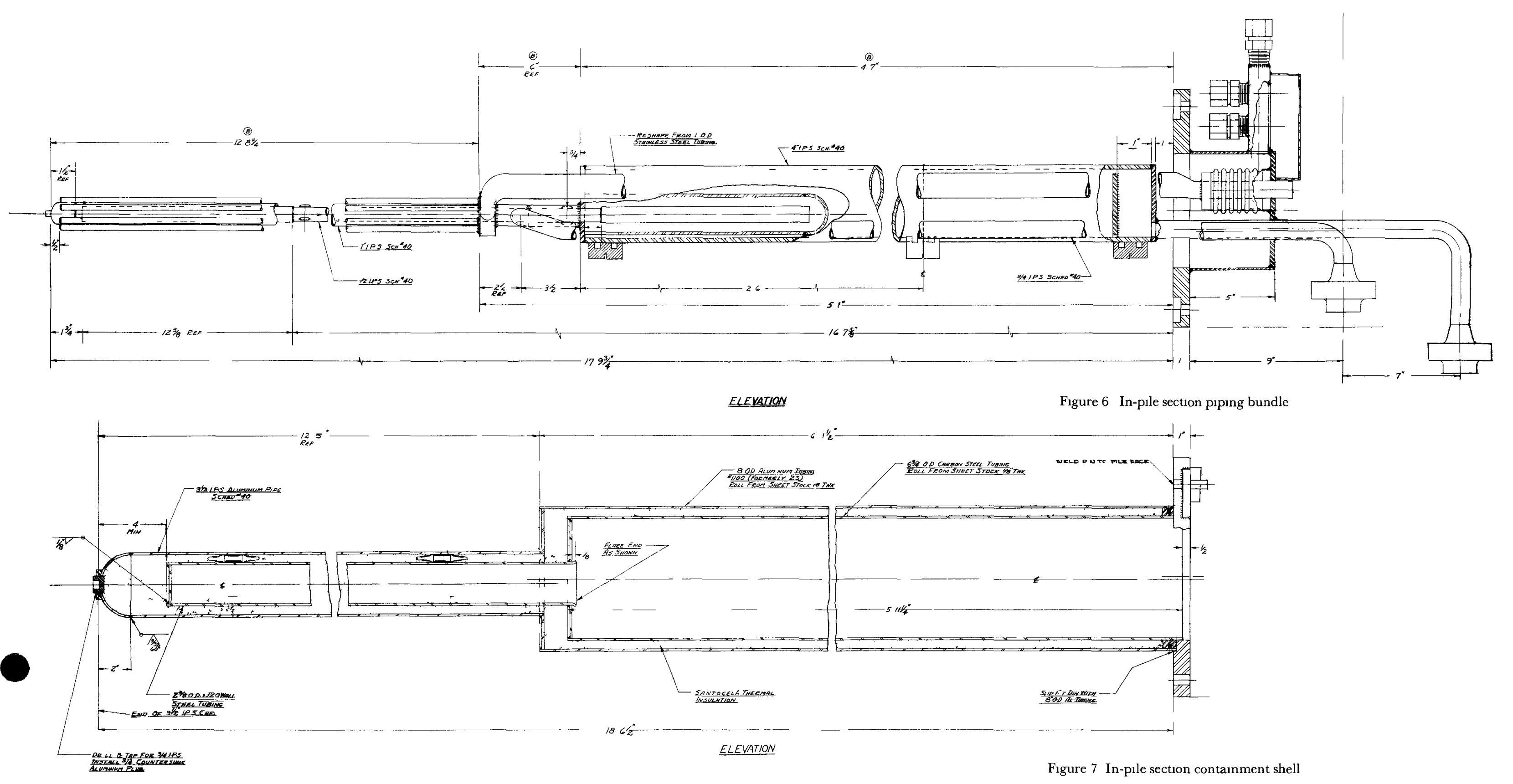




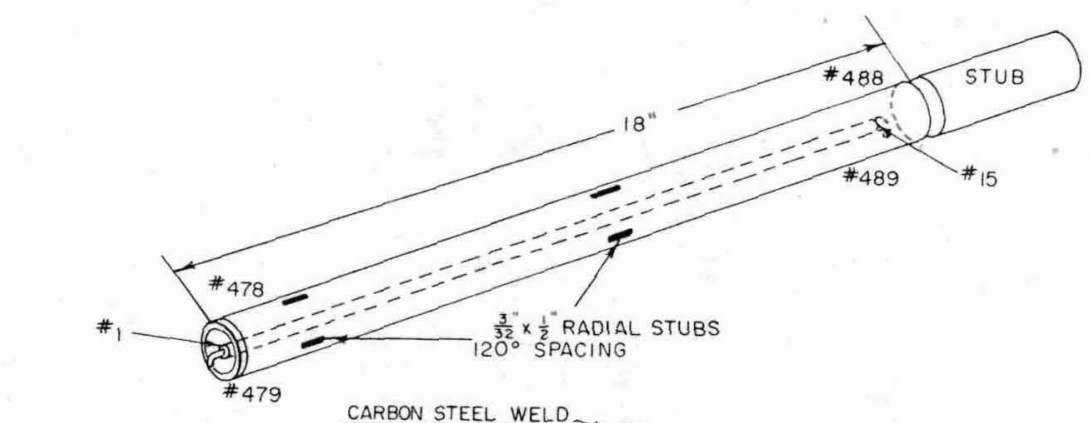

CROSS SECTION AT
SUPPORT ENDS

Figure 9. In-pile test section, exterior view.

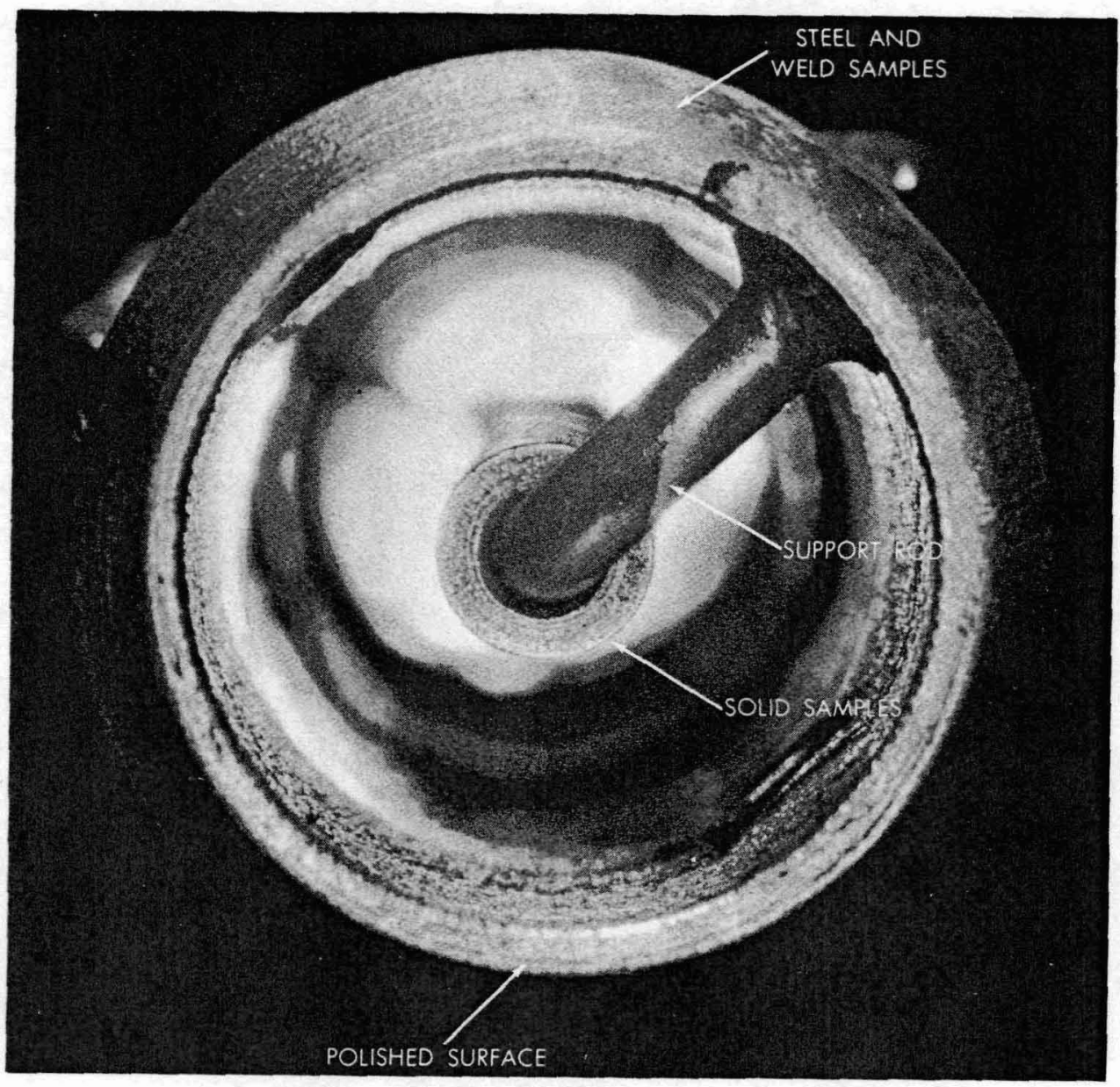

Figure 10. In-pile test section, end view. 


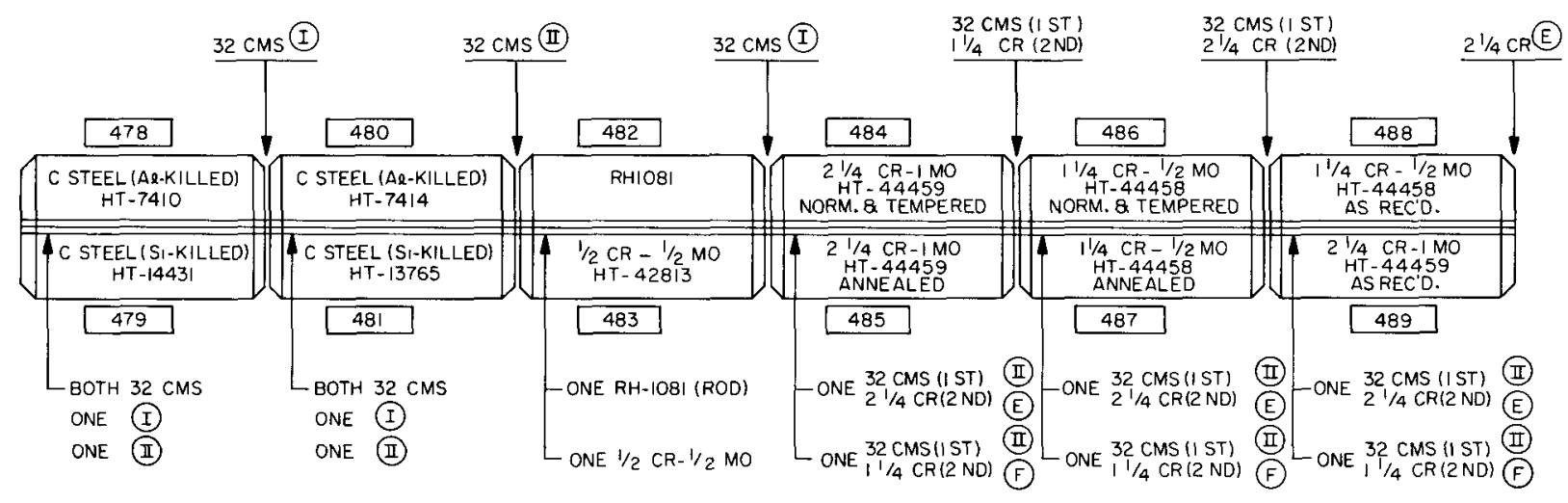

NOTES

Circled symbols denote lot used

NOT TO SCALE

All specimens were cylindricol and were bored and polished for $1 / 2$ of length on the ID

Completed section stress-relieved I hr. C $1350{ }^{\circ} \mathrm{C}$ in vocuum.

O.D. of completed section machined "ciean" after stress-relief operation.

Figure 12. In-pile test section, metal corrosion specimens.

Table 2

\begin{tabular}{|c|c|c|}
\hline & Material & Source \\
\hline Sample No. & \multicolumn{2}{|l|}{ A. Cylindrical Welded Samples } \\
\hline 478 & Carbon steel, Al-killed & Bar \#141B, National Tube, HT 7410 \\
\hline 479 & Carbon steel, Si-killed & Bar \#125I, National Tube, HT 14431 \\
\hline 480 & Carbon steel, Al-killed & Bar \# 142B, National Tube, HT 7414 \\
\hline 481 & Carbon steel, Si-killed & Bar \#126D, National Tube, HT 13765 \\
\hline 482 & Carbon steel, low Mn & Bar \#103, Jones \& Laughlin, RH 1081 \\
\hline 483 & $1 / 2 \% \mathrm{Cr}-1 / 2 \% \mathrm{Mo}$ & Bar \#013, B\&W, HT 42813 \\
\hline 484 & $21 / 4 \% \mathrm{Cr}-1 \% \mathrm{Mo}$ & Bar \#060H, B\&W, HT 44459 \\
\hline 485 & $21 / 4 \% \mathrm{Cr}-1 \% \mathrm{Mo}$ & Bar \#060H, B\&W, HT 44459 \\
\hline 486 & $11 / 4 \% \mathrm{Cr}-1 / 2 \% \mathrm{Mo}$ & Bar \#067E, B\&W, HT 44458 \\
\hline 487 & $1 \frac{1}{4} \% \mathrm{Cr}-1 / 2 \% \mathrm{Mo}$ & Bar \#067E, B\&W, HT 44458 \\
\hline 488 & $11 / 4 \% \mathrm{Cr}-1 / 2 \% \mathrm{Mo}$ & Bar \#067C, B\&W, HT 44458 \\
\hline 489 & $21 / 4 \% \mathrm{Cr}-1 \% \mathrm{Mo}$ & Bar \#060H, B\&W, HT 44459 \\
\hline Stub & $2 \frac{1}{4} \% \mathrm{Cr}-1 \% \mathrm{Mo}$ & Bar \#060H, B\&W, HT 44459 \\
\hline Lot No. & \multicolumn{2}{|l|}{ B. Weld Rod } \\
\hline I & 32 CMS & Linde \\
\hline II & 32 CMS & Linde \\
\hline $\mathrm{E}$ & $21 / 4 \% \mathrm{Cr}-1 \% \mathrm{Mo}$ & Arco, HT 4531 \\
\hline $\mathrm{F}$ & $1 \frac{1 / 4}{2} \mathrm{Cr}-1 / 2 \% \mathrm{Mo}$ & Arco, HT 4638 \\
\hline RH 1081 & Carbon steel, low Mn & Cut from Bar 103 \\
\hline- & $1 / 2 \% \mathrm{Cr}-1 / 2 \% \mathrm{Mo}$ & Cut from Bar 013 \\
\hline Sample No. & \multicolumn{2}{|l|}{ C. Solid Samples } \\
\hline 1 & Molybdenum & Fansteel \\
\hline 2 & MH4HLM graphite & Great Lakes \\
\hline 3 & 237 graphite & Great Lakes \\
\hline 4 & CEY graphite & Great Lakes \\
\hline 5 & Graphitite G & Graphite Specialties \\
\hline 6 & R0020 graphite & National Carbon \\
\hline 7 & Beryllium & Brush Beryllium, type QMV \\
\hline 8 & Molybdenum-0.5 Ti & Fansteel \\
\hline 9 & EY9 graphite & British \\
\hline 10 & R0025 graphite & National Carbon \\
\hline 11 & Graphitite A & Graphite Specialties \\
\hline 12 & R-4 graphite & Graphite Specialties \\
\hline 13 & MH4HLM graphite & Great Lakes \\
\hline 14 & ATL82 graphite & National Carbon \\
\hline 15 & Tantalum & Haynes Stellite \\
\hline Support rod and radial stubs & $21 / 4 \% \mathrm{Cr}-1 \% \mathrm{Mo}$ & Weld rod lot E \\
\hline Graphite spiders & Graphitite G & Graphite Specialties \\
\hline
\end{tabular}




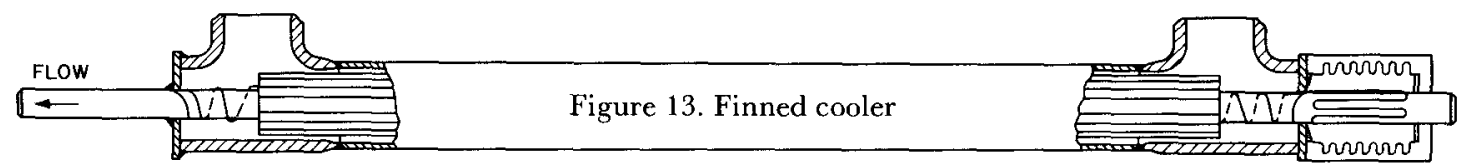

\section{Furnace}

The induction furnace was a 7.5-ft section of 3/4-in. Sch. 40 pipe about which was fitted a 3-in.o.d. steel billet. The billet was insulated with 4 in. of Superex-X and 2 in. of $85 \%$ magnesia insulation. The entire assembly was wrapped with $4 / 0$ AVA stranded Cu wire on a pitch of 11 turns/ft and was rated at $7 \mathrm{kw}$. The furnace was controlled either by a thermocouple located in a well at the exit from the in-pile section or by one located on the billet itself, depending on whether the $\mathrm{Bi}$ was circulating or not.

\section{Cooler}

The cooler (Figure 13) consisted of a $3.5-\mathrm{ft}$ length of $3 / 4-i n$. Sch. 40 pipe upon which were welded 18 stainless steel fins $1 / 2$ in. high $\times 0.24$ in. thick $\times 3 \mathrm{ft}$ long and spaced $20^{\circ}$ apart. The tube was placed inside a 31/4-in.-o.d. $\times^{1 / 4-i n}$.-wall carbon steel shell. A carbon steel bellows was attached to one end of the shell to compensate for thermal expansion. Heater wire was wrapped longitudinally between the fins to provide preheat and emergency heating in the event of overcooling. Cooling air was pulled from the room, filtered, and passed concurrently through the shell by a fan rated at $100 \mathrm{cfm}$. The coolant was then filtered and discharged outside the building. Air flow across the finned section was controlled by a remotely operated by-pass valve located at the fan suction and three manual valves which could reduce the effective length of the cooler by $1 / 3$ and $2 / 3$. A thermostatic throttle damper for fine flow adjustment was located at the cooler inlet duct and was controlled by a thermocouple located in the bulk fluid at the exit from the cooler.

\section{Intermediate Heat Exchanger}

The intermediate or regenerative heat exchanger, shown in Figure 14, was a U-shaped shell-and-
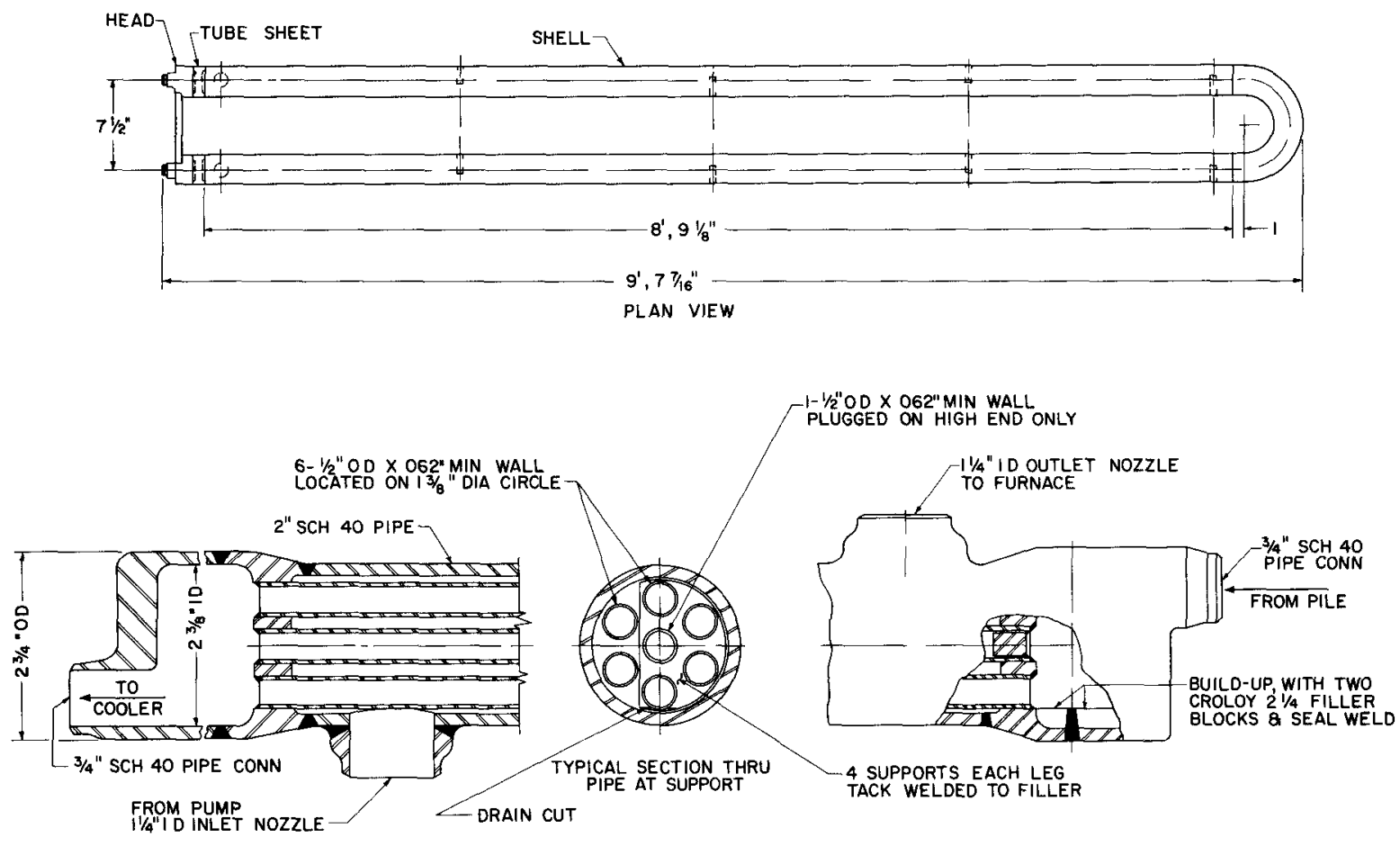

Figure 14. Intermediate heat exchanger. 
tube type. The unit was made up of 7 tubes, each approximately $18 \mathrm{ft}, 8 \mathrm{in}$. long, with a $1 / 2$-in. o.d. and a 0.062 -in.-thick wall inside a 2 -in. Sch. 40 pipe shell. Liquid metal flow through the unit was countercurrent with the hottest fluid on the tube side.

\section{Deposition Gauge}

A high temperature, remotely operated gauge to measure the deposition of $\mathrm{Fe}$ in pipes was developed for use in the Radiation Loop. ${ }^{1}$ Because of the high level activity from the $\mathrm{U}^{235}$ fission products, radiographic methods could not be used. The gauge was located at the exit from the cooler and was maintained at the lowest temperature in the loop, $425^{\circ} \mathrm{C}$, to insure that any deposition would occur at this point. The gauge utilized a magnetic bridge to compare the reluctance of a magnetic circuit incorporating the pipe to be measured to another magnetic circuit containing a standard pipe section. If either corrosion or deposition of ferromagnetic material occurred in the pipe, there would be a change of reluctance which was calibrated in terms of quantity of ferromagnetic material in the measured pipe. Figure 15 shows the assembled yoke and coils.

Figure 16 is a schematic diagram of the measuring device. A $3 / 4$-in. Sch. 40 pipe 24 in. long containing the U-Bi fuel $(A)$ was connected to the dummy pipe $(B)$ by means of an ingot Fe yolk $(G$, $E$ ). A pair of primary coils ( $C$ and $D$ ) were wound in series around the yoke so that a current passing through the coil produced a magnetic field as indicated by the arrows. Initially the reluctance around the path $A-E$ was balanced by that around path $B-E$, and no voltage was induced in the pickup coil $(F)$ wound around the central leg of the yoke $(E)$. If, however, there was either corrosion or ferromagnetic deposit in the pipe containing $\mathrm{Bi}$, the reluctance around path $A-E$ would change, and an error signal would be induced in the pickup coil. This would then be amplified and fed to a phase detector. The detector output was calibrated in terms of pipe thickness and could sense 0.010 in. or better.

Before a measurement could be made, the region to be measured had to be brought to a reproducible magnetic state. This was accomplished by surrounding the gauge with a demagnetizing coil. A field of 1800 amp-turns was found to be sufficient to remove any residual magnetism produced by the primary coils.

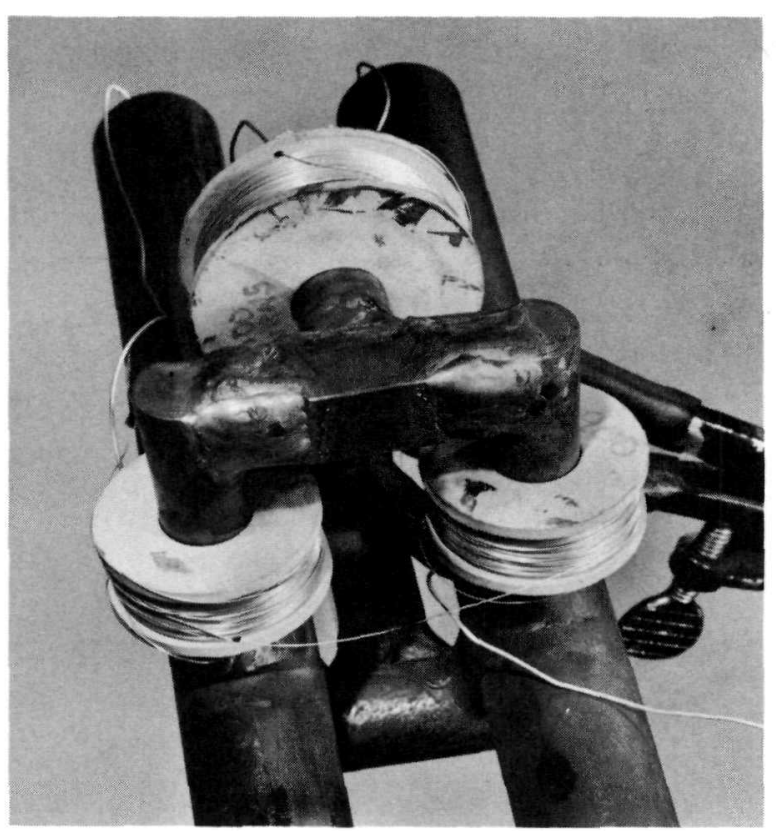

Figure 15. Deposition gauge.

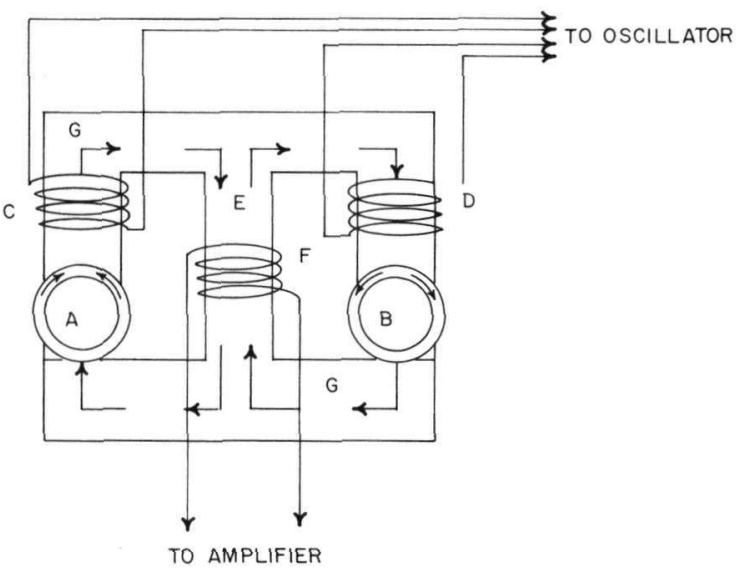

Figure 16. Deposition gauge circuit.

To operate the gauge between $400^{\circ}$ and $500^{\circ} \mathrm{C}$, the coils had to be capable of withstanding these temperatures. Ordinary insulated $\mathrm{Cu}$ wire could not be used, but anodized $\mathrm{Al}$ was found to be satisfactory and had the further advantage that more windings per unit volume could be obtained than with conventional glass insulated wire.

The gauge used in the loop had a field intensity of 15 amp-turns per inch around the core. An 80 -cycle square wave was used to supply the primary coils. This low frequency was chosen to avoid a skin effect around the pipe, which would reduce 
sensitivity, and to make it possible to discriminate between pickup from the gauge circuit and pickup from stray 60-cycle current.

\section{Flowmeter}

The rate of U-Bi flow in the Radiation Loop was measured by a thermal balance flowmeter," chosen because it required no moving seal such as a bellows, had no moving parts, and eliminated any chance of precipitation of $\mathrm{Fe}$ due to a magnetic field as in electromagnetic flowmeters. The flowmeter operated on the heat balance principle. If the heat input to a moving stream and the resulting temperature rise are known, the flow rate can be calculated by the relationship

$$
Q=W c_{p} \Delta T,
$$

where

$$
\begin{aligned}
Q= & \text { heat input to the flowing stream in } \\
& \text { Btu } / \mathrm{hr}, \\
c_{p}= & \text { heat capacity of fluid in Btu } / \mathrm{lb}-{ }^{\circ} \mathrm{F}, \\
W= & \text { weight of fluid flowing in the sys- } \\
& \text { tem in } \mathrm{lb} / \mathrm{hr}, \\
\Delta T= & \text { fluid temperature difference, }{ }^{\circ} \mathrm{F} .
\end{aligned}
$$

The flowmeter (Figure 17) consisted of a 21-in. section of flattened 2-in. Sch. 40 pipe through which two tubular heating elements were passed. The 2-in. pipe was flattened to insure proper drainage when the loop was dumped and to eliminate gas pockets. The heating elements were each rated at $2000 \mathrm{w}$ at $220 \mathrm{v}$. They consisted of a nichrome $\mathrm{V}$ heating element covered by magnesium oxide insulation which was in turn sheathed by $1 / 2$-in. tubing of $2 \frac{1}{4} \% \mathrm{Cr}-1 \%$ Mo steel.

Temperature measurement was made by thermopiles located in wells at the entrance to and exit from the heated section. Each thermopile consisted of ten chromel-alumel thermocouples connected in series so that the developed voltage was increased by a factor of ten. The thermopiles were electrically insulated from the flowmeter to avoid shortcircuiting through the pipe wall. They were connected electrically to indicate the difference in temperature. The flowmeter was operated on a semicontinuous basis. Twice an hour the heaters were triggered by a timer, and the temperature difference, which was recorded continuously, indicated the change due to heating.

Prior to use in the Radiation Loop, the flowmeter was installed in a test facility and compared with an electromagnetic flowmeter and an orifice.
The thermal flowmeter operated without difficulty for $851 \mathrm{hr}$ and was in close agreement with the other flowmeters. Figure 18 shows the flowmeter installed in the Radiation Loop before it was insulated.

\section{Pump}

Circulation in the Radiation Loop was provided by a canned, overhung-impeller, sump-type centrifugal pump with a 10 -hp, 3450-rpm, 3-phase motor. Figure 19 shows the major design features of the pump, which was equipped with a 3.5-in.diam 5-bladed impeller. The pump was mounted in a 12 -in. IPS can to which a 30 -in.-i.d. bustle was welded to make it large enough to accommodate the entire circulating Bi charge.

To insure draining of the in-pile section in the event of pump or loop failure, and to eliminate the need for dumping the loop to the dump tank each time flow was stopped, the pump was located at the low point of the circulating system. The U-Bi was forced into the loop when the pump was started and was drained from the loop as soon as the pump was shut down. The pump can and bustle were filled with the entire operating charge by forcing the U-Bi into it from the melt and dump tank with gas pressure. To facilitate drainage of the in-pile section, the pump inlet was located in the gas phase at the top of the bustle. A 4-probe liquid-level device attached to the pump showed the Bi level in the can.

Difficulties were encountered in the selection of bearings and lubricants. Out-of-pile testing of the pump at design conditions resulted in three bearing failures for which no specific cause could be determined. Possibilities considered were high operating temperatures $\left(>52^{\circ} \mathrm{C}\right)$, excessive loading due to the overhung shaft design, and lubricant failure. The bearings finally used were a singlerow, deep-groove type with increased ball and race clearances, lubricated with Texaco Uni-Temp 500 grease. The lubricant was advertised as suitable for use at temperatures up to $177^{\circ} \mathrm{C}$ for continuous operation. Studied by the manufacturer under static conditions at $10^{8} \mathrm{rad}$ with a $\mathrm{Co}^{60}$ source, the grease softened on an unworked basis but was not significantly affected on the basis of the worked penetration.

The pump was tested for $1287 \mathrm{hr}$ in a pump test facility before installation in the loop. A shutoff head of 157 psi and a developed head of 150 psi 


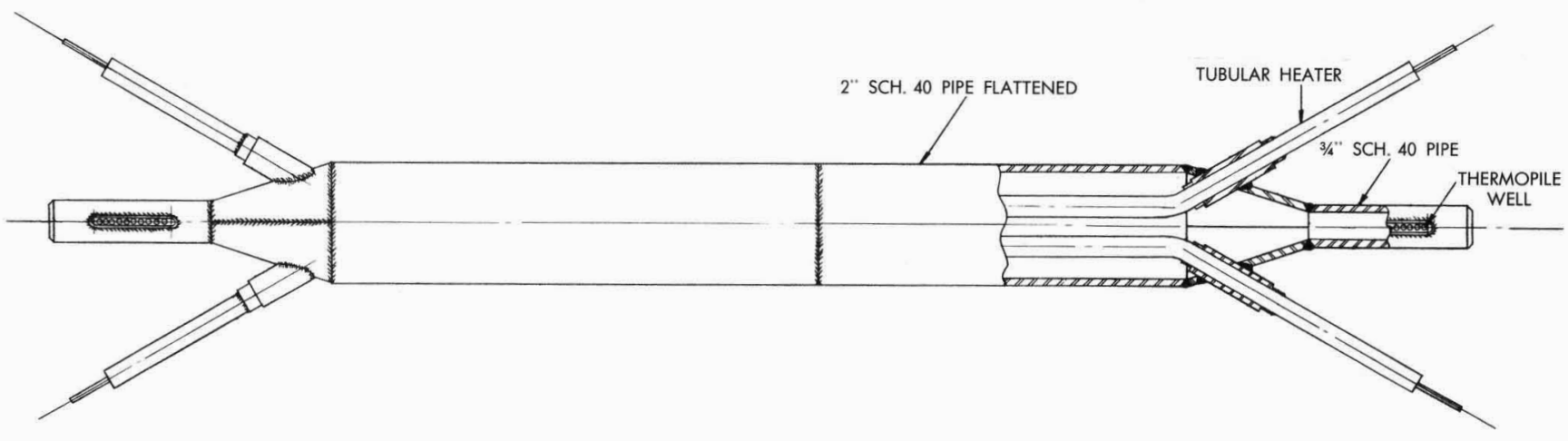

Figure 17. Thermal flowmeter.

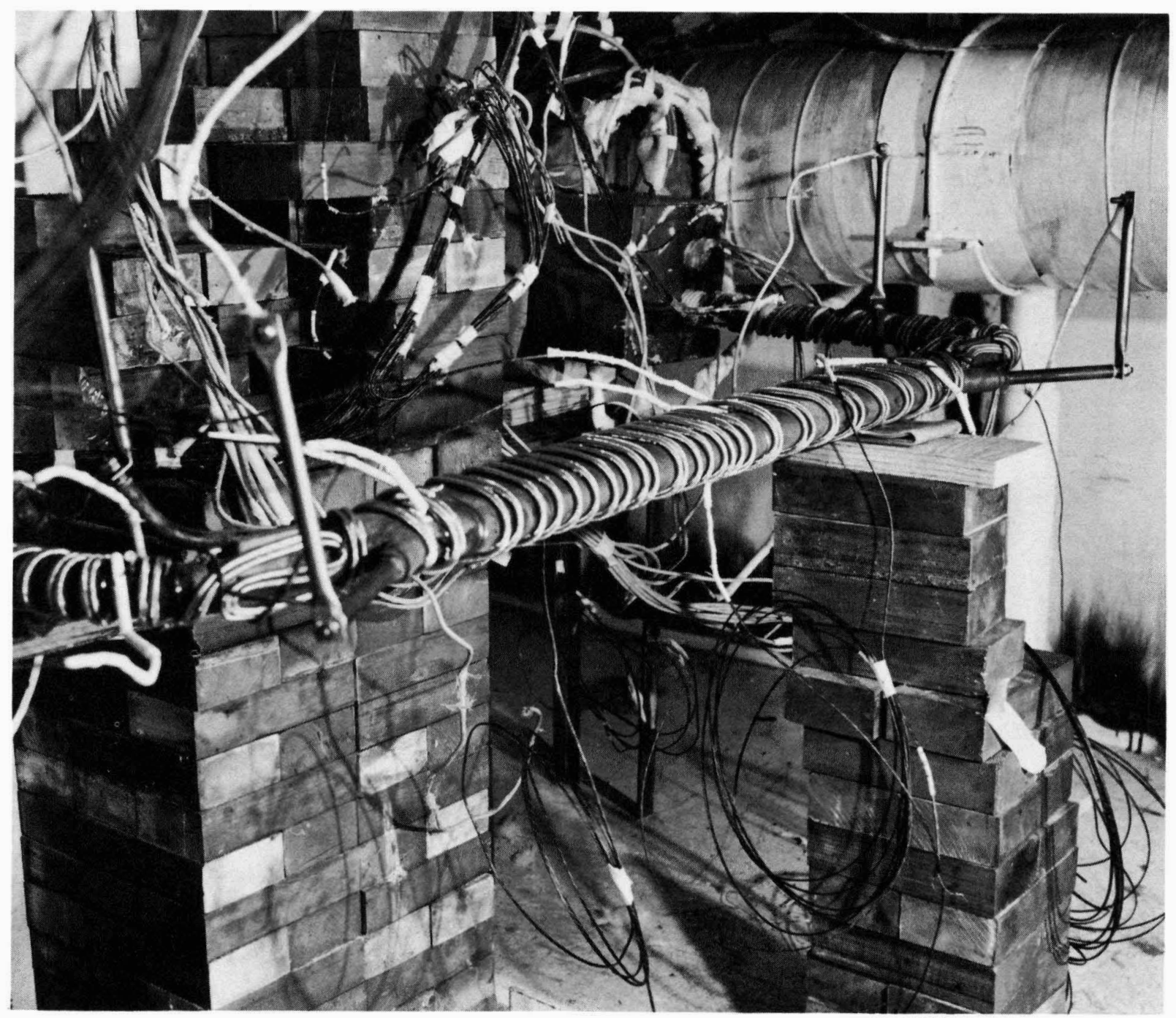

Figure 18. Flowmeter installation. 


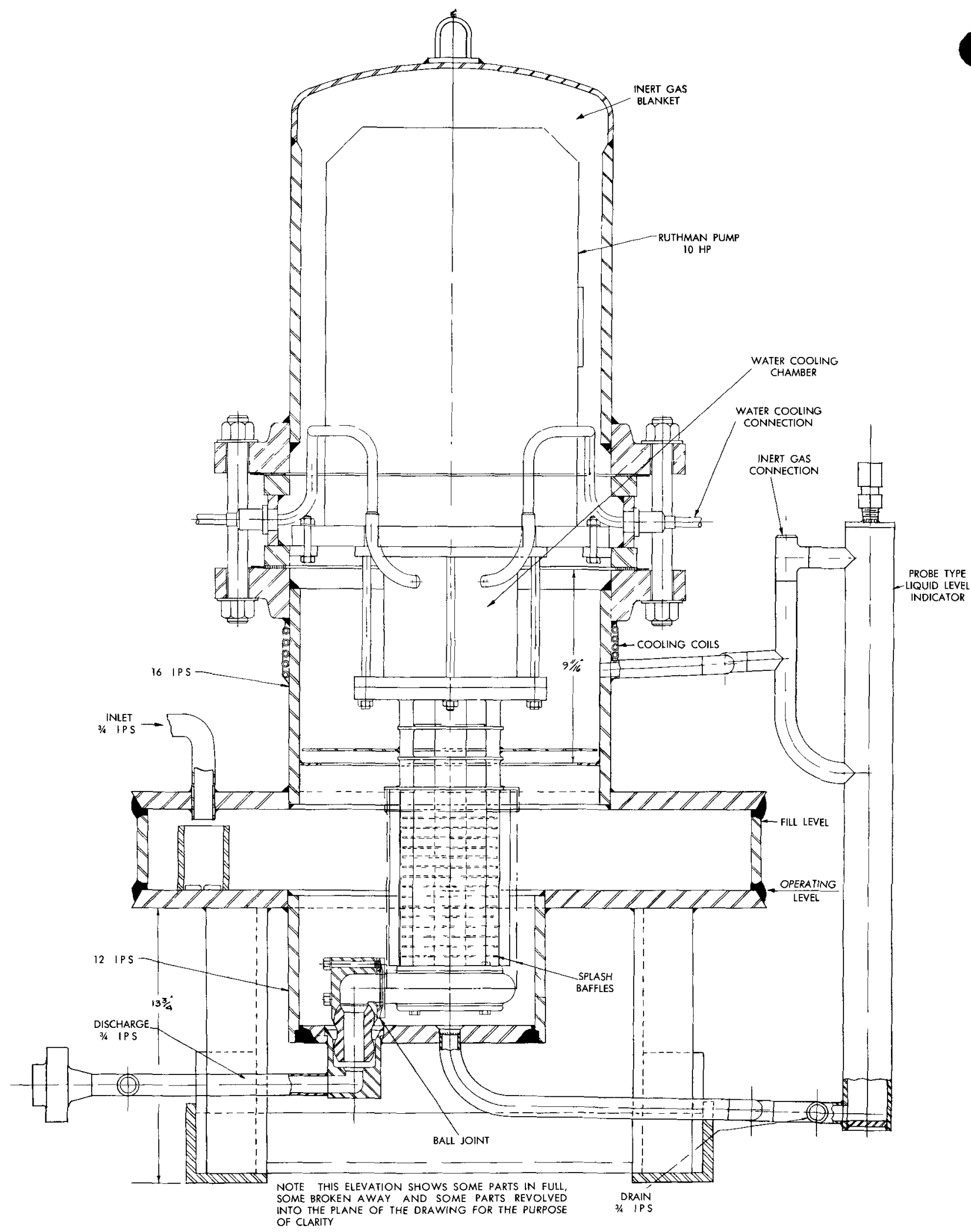

Figure 19. Radıation Loop pump. 
at a full flow of $9.5 \mathrm{gpm}$ were obtained. An efficiency of $12 \%$ at full flow and a loop ballast pressure of 25 psig were obtained. The pump characteristics are shown in Figure 20.

\section{Sampler}

One of the major problems associated with the Radiation Loop was the development of a means of sampling the test fluid. It was necessary to sample the radioactive U-Bi fuel both from the flowing stream and from the stagnant melt and dump tank under pressures up to 40 psig and sampling point activity of the order of $100 \mathrm{r} / \mathrm{hr}$. All samples had to be filtered and taken in graphite cups. The radioactive nature of the test fluid dictated a gas-tight device with a minimum of direct handling. A hermetically sealed, remotely operated sampler with provisions for semiremote maintenance or replacement was developed. Figure 21 is a schematic of this sampler, which was operated as follows.

The graphite bucket was inserted into the loading tube (1) and through the gas lock to rest on top of piston (3). When piston (3) was moved to the right, the bucket dropped into hole (2) in the piston. When piston (3) was then moved to the left, the bucket dropped into hole (5) in piston (6). Hole (5) was a snug fit, and, to insure that the bucket was properly seated, piston (4) was moved down to force the bucket into hole (5). Piston (6) was then moved to the left until hole (5) was directly under plunger (7), which moved down with piston (8) to force-fit the bucket on the plunger. Pistons (8), (6), and (3) were then retracted to their original positions. The bucket was then ready to take a sample.

Piston (8) was then moved down through a ball valve which separated the sampler from the loop proper until trigger (10) met stop (9); at this point the bucket was in the melt. As piston (8) continued to move down, trigger (10) caused the release of piston (11), which under spring action moved upward and caused a volume expansion with a resulting pressure decrease within the sampling tube. The higher external pressure then forced the filtered U-Bi sample into the bucket. The sampling was then complete and the bucket was ready for removal from the sampler.

Piston (8) was then retracted to its uppermost position, and piston (15) was moved to the right so that hole (13) was under the graphite bucket. Piston (12) then pushed down on piston (11) and cocked it, which forced the bucket from the holder.

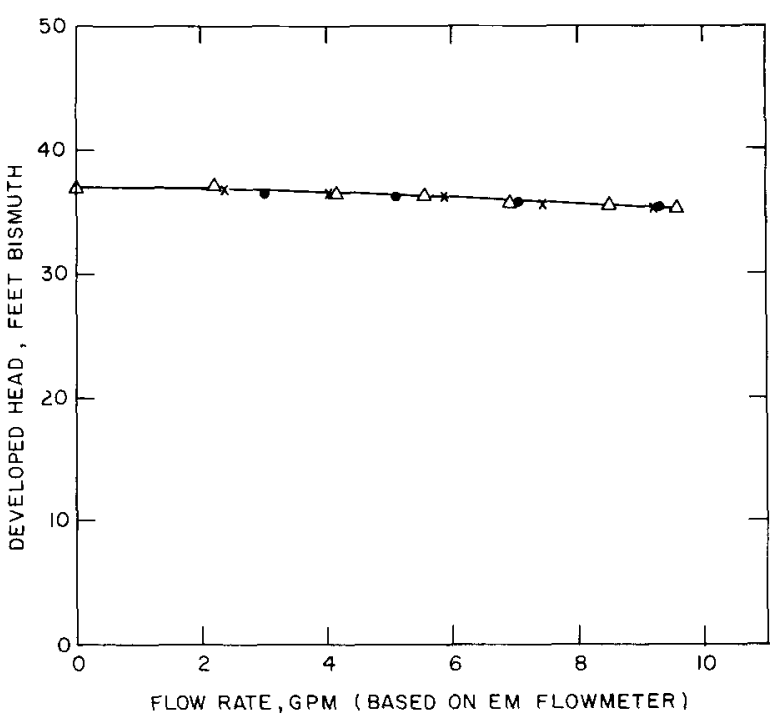

Figure 20. Pump characterıstics - Head vs flow rate

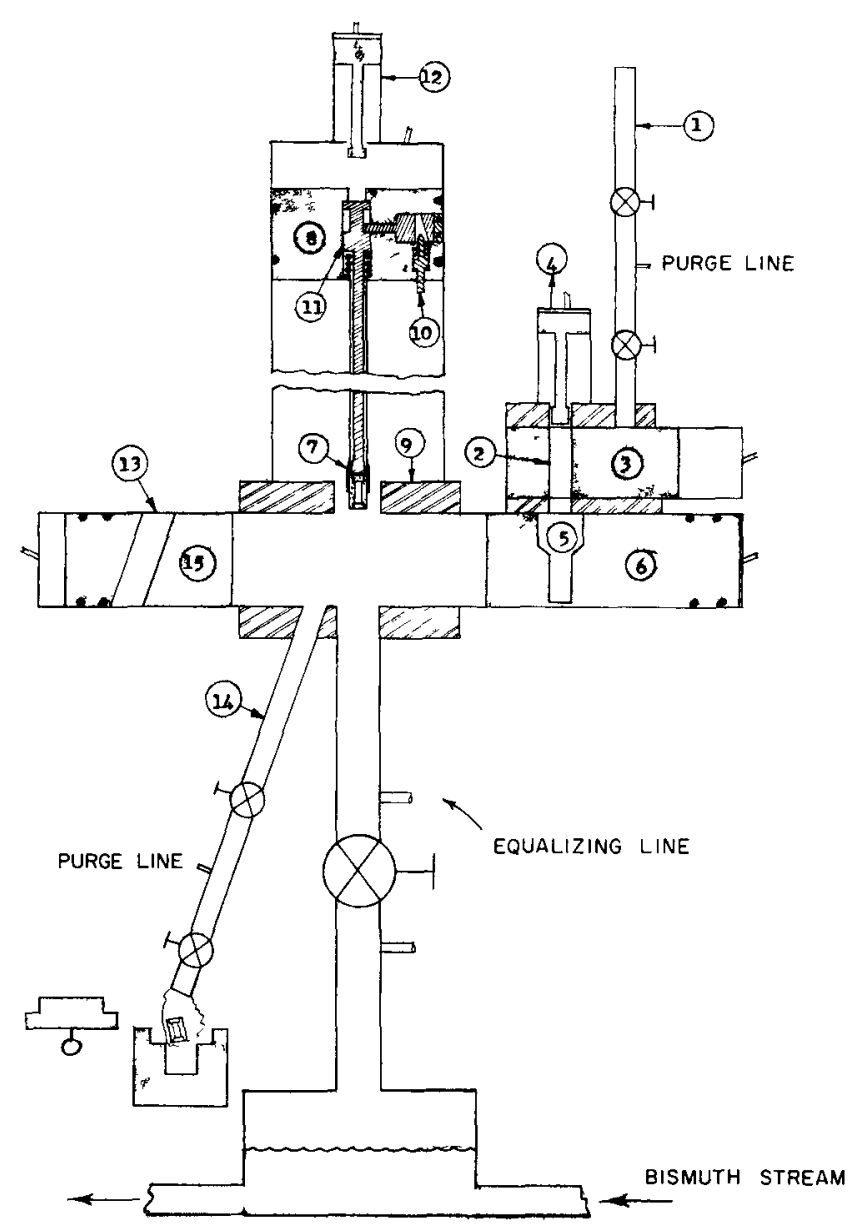

Figure 21 Remote sampler, schematic. 
The bucket then fell into hole (13), passed through tube (14), and was discharged into a polyethylene bag in a lead pig.

After having been tested in a bench facility, the samplers were installed in the loop. Figure 22 shows the in-line sampler in place.

\section{Valves}

Two types of $\mathrm{Bi}$ valves were used in the Radiation Loop. Because of lack of information on the reliability of $2 \frac{1}{4} \% \mathrm{Cr}-1 \%$ Mo steel bellows, a valve was developed having a graphite-to-metal seat with a gas backup and a graphite-to-metal backseating arrangement to prevent Bi leakage about the valve stem. A stainless steel bellows was used to contain the blanket gas. Two of these valves served as dump valves in the loop. A 3/4-in., doublebellows globe valve was also installed in the system to act as a spare in the event of failure of either of the graphite disc valves. A second double-bellows

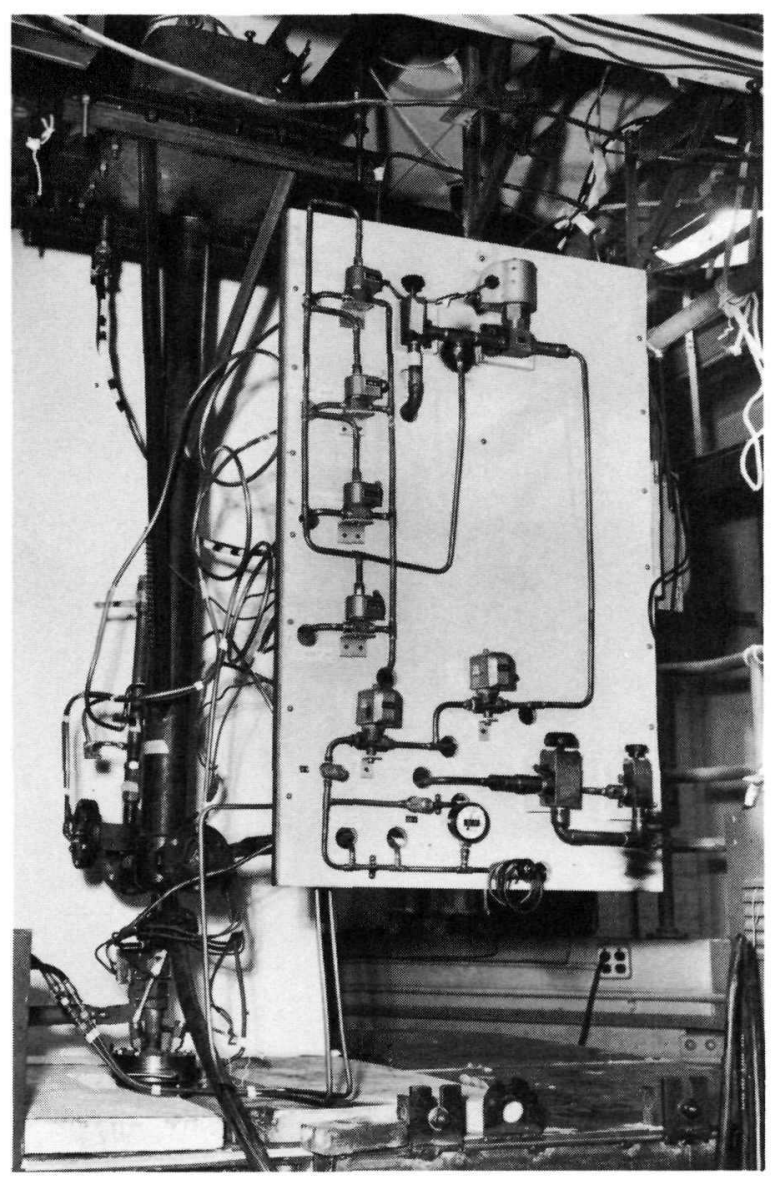

Figure 22. Remote sampler, installed. valve was installed between the melt and dump tank and the cold disposal tank for use when flushing the loop at the completion of the run.

Graphite Disc Drain Valve. Development of the graphite disc drain valve was undertaken by using a graphite-to-metal seat with a gas backup to prevent leakage about the valve stem. Prototype testing was done in an apparatus simulating the operating conditions of the Radiation Loop. The operating conditions and requirements considered in designing the valve are given below.

A. Operating conditions

1. Pressure differential across the seat, 140 psi.

2. Valve temperature, $538^{\circ} \mathrm{C}$ minimum.

3. Service time, 5000 to $15,000 \mathrm{hr}$.

4. Bi activity, $1 \mathrm{C} / \mathrm{cc}$.

B. Requirements

1. Bi leakage across seat, $<20 \mathrm{lb} / 1000 \mathrm{hr}$.

2. No damage due to thermal cycling.

3. No damage due to repeated opening and closing of valve.

4. No damage due to Bi corrosion of seat.

5 . No detrimental effects due to high radiation dosage.

6. No gas or liquid metal leakage.

7. Remote operation.

After three prototypes had been built and tested, a valve was developed that met the above requirements. Figure 23 is an assembly drawing of the final design. The unique features of this valve are the double graphite-to-metal seating arrangement and the fact that the bellows is not in contact with the Bi. A stainless steel bellows high on the shaft prevented gas leakage.

The valves were equipped for remote operation with an air operator that had a 4-in.-diam piston which at 80 psig exerted a stem force of $1005 \mathrm{lb}$. The force needed to compress the bellows and the lifting force on the seat due to the pressure differential $(\Delta P)$ reduced the stem force to $\approx 870 \mathrm{lb}$. The seating pressure on the graphite disc was 3500 psi. This pressure was increased by impact loading when the valve was being closed and also in the absence of a $\Delta P$ across the seat; however, it was always within the compression strength of the HLM graphite. The valve was tested to determine the leak rate across the seat and the effects of cycling. A test with a $\Delta P$ of 60 psi across the seat and with 80 psig on the pneumatic operator indicated that cycling produced no detrimental effects. The leak rate after 1001 cycles was found to be less 
than the initial value. This condition was expected, since graphite deforms plastically to align itself with the seat. With a seat $\Delta P$ of 140 psi and 80 psig on the pneumatic operator, a leak rate of $1.1 \mathrm{lb} /$ $1000 \mathrm{hr}$ was obtained.

A 410 stainless steel, 30 to $40-\mu$ filter was placed on the dump-tank side of the valve to prevent the deposition of suspended particles on the seat or disc. This was later removed with no apparent adverse effect on the operation of the valve.

Bellows-Sealed Globe Valves. Two 3/4-in., 200$\mathrm{lb}$, double-bellows-sealed globe valves, purchased from the William Powell Co., were also installed in the loop in locations where contact with the Bi was limited. Each valve was equipped with two

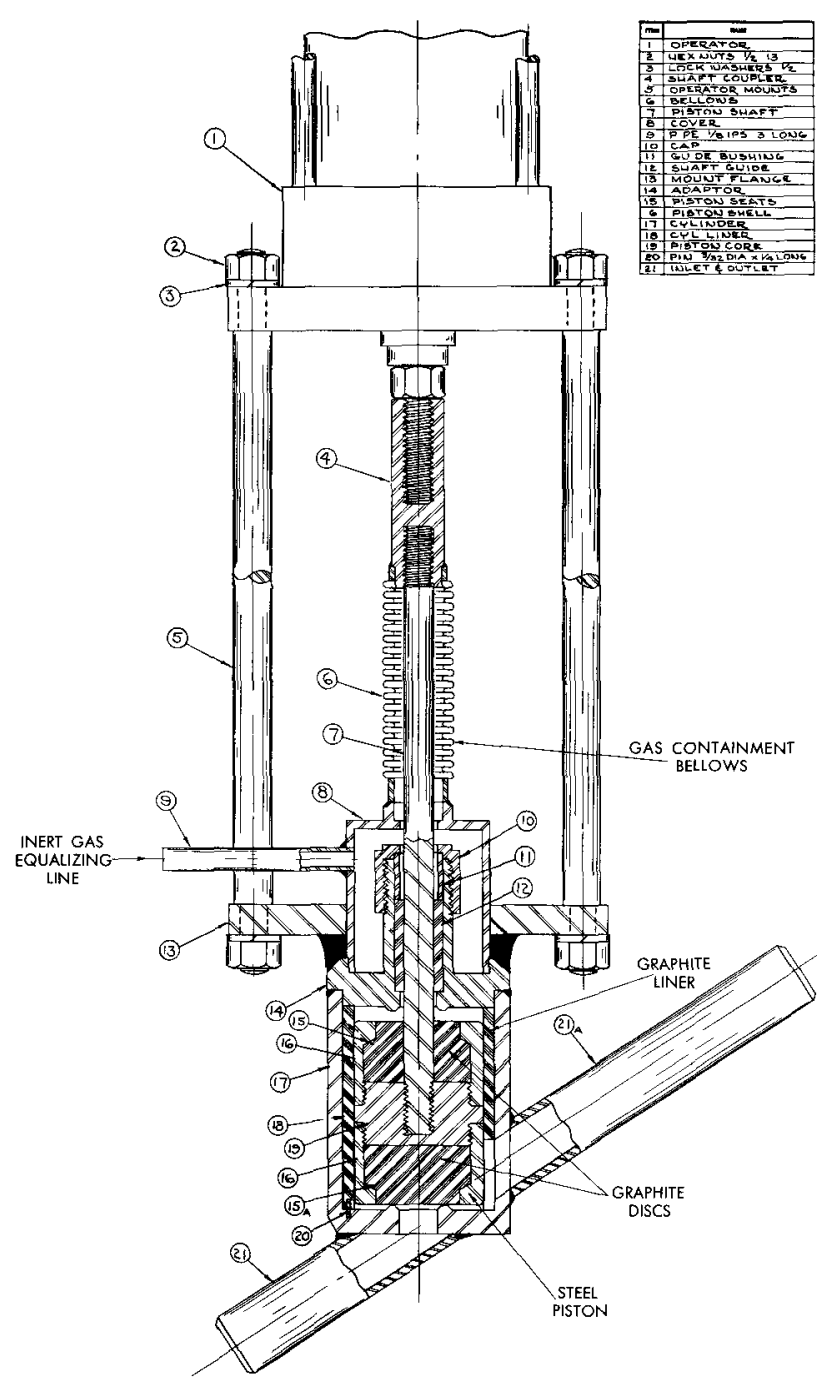

Figure 23. Graphite disc drain valve. bellows constructed of $2 \frac{1}{4} \% \mathrm{Cr}-1 \%$ Mo steel as a protection against leakage. Each valve was also equipped with an air operator for remote operation. Figure 24 is an assembly drawing of the valve.

\section{INERT GAS AND VACUUM SYSTEM}

A He blanket was maintained over the U-Bi solution to prevent the oxidation of the $\mathrm{U}, \mathrm{Mg}$, and $\mathrm{Zr}$ additives. This gas was also used to transfer the fluid charge from the dump tank into the loop and between the various dump-tank vessels. A vacuum system was installed to evacuate the loop to $\approx 1 \mu$, $\mathrm{Hg}$ pressure for leak testing and outgassing purposes. These systems are shown in detail in Figure 1.

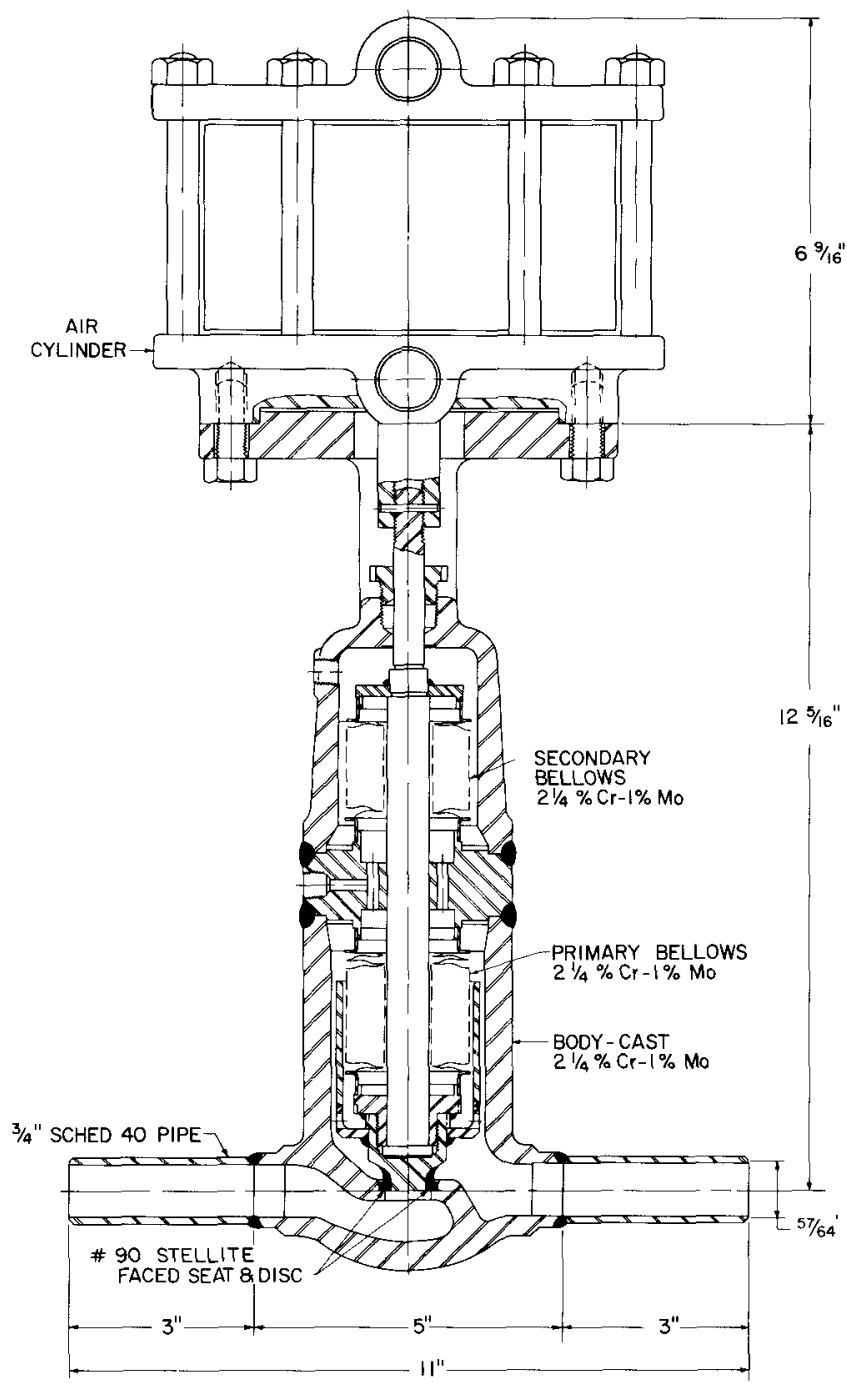

Figure 24. 3/4-in. Bellows-sealed valve (Wm. Powell Co.). 


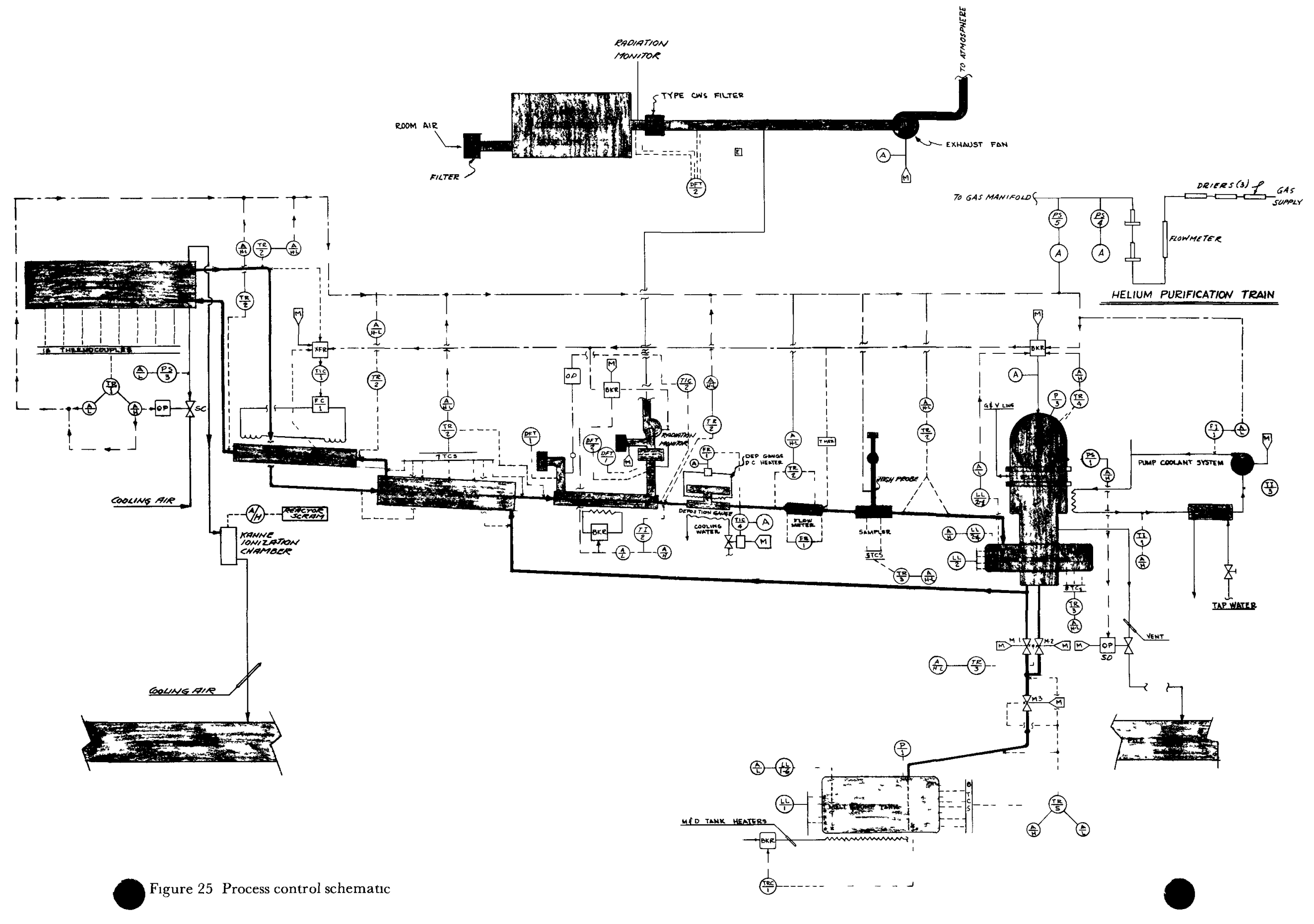


The entire gas and vacuum system was fabricated of $\mathrm{Cu}$ with sweat connections. The tubing sizes ranged from $1 / 4$ to $2 \mathrm{in}$. in diameter.

A gas purification train was installed on the main supply to remove any traces of oxygen from the He. This unit consisted of silica-gel dryers, two Ti packed bed units maintained at $600^{\circ} \mathrm{C}$, and storage tanks. The purity of the gas was tested by passing the gas over a polished chip of U maintained at $600^{\circ} \mathrm{C}$. Any discoloration of the chip was cause for rejection of the gas. No difficulties were encountered with this unit.

The high-vacuum system consisted of a liquid nitrogen cold trap, a diffusion pump, a fore-pump, and appropriate valves and gauges. A servicevacuum system with a mechanical pump was also provided for use during sampling and transfer operations.

\section{PROCESS CONTROL}

The control systems installed in the loop to regulate the upper and lower fluid temperatures and to provide for equipment and personnel safety are shown in detail in Figure 25.

The heat input to the loop was provided by the induction furnace, flexible armor-sheathed nichrome heater wire, and tubular heaters. Provision was made for three operating conditions. When empty, the piping was maintained at temperature. In this condition, the heaters compensated for the normal heat losses. During isothermal operation with flow, the loop temperature was uniform and the heaters were reduced to compensate for the input due to pump inefficiency. The normal operating condition involved circulating the $\mathrm{Bi}$ through a temperature difference $(\Delta T)$ of $75^{\circ} \mathrm{C}$ measured from the in-pile tip to the deposition gauge. In this case, heat was supplied by the furnace and by fission and gamma heating and was removed in the cooler. Some piping heaters were left turned on to make up heat losses in other parts of the loop and to prevent the temperature from falling below the deposition gauge temperature.

The highest $\mathrm{Bi}$ temperature $\left(500^{\circ} \mathrm{C}\right)$ was reached at the top of the in-pile section and was read by a well-thermocouple. The tip thermocouple was compared to a well-thermocouple located on the in-pile section outlet. The latter thermocouple sensed the temperature resulting from the combined heat input of the furnace and the in-pile fis- sion and gamma heating. The outlet couple was then used to control the furnace input, thereby controlling the total heat input to the loop. When the Bi flow was stopped, the furnace was protected from overheating by switching its control to a thermocouple located on the furnace body. All the thermocouples were chromel-alumel.

The lowest $\mathrm{Bi}$ temperature $\left(425^{\circ} \mathrm{C}\right)$ was measured by a thermocouple located at the deposition gauge and correlated with a thermocouple located at the cooler outlet. The cooler outlet thermocouple signal was then used to control the supply of air to the cooler as described previously. The furnace and cooler temperatures varied $<2.5^{\circ} \mathrm{C}$ during normal $\Delta T$ operation.

All piping and components were monitored for excessively high or low temperature, and either condition caused the loop to dump by stopping the pump. In such instances the Bi remained in the pump until the operator chose to discharge it to the melt and dump tank. Dumping also took place when the pump motor overheated, the pump water cooling failed, a low liquid level occurred in the sampler or pump, or a high level of activity was detected with the in-pile section monitor. Also monitored were the pump coolant temperature, instrument air and inert gas pressure, containment and cooler air activities, emergency cooling air supply, and the pump pressure. Other process conditions of temperature, pressure, and flow were observed but did not trigger alarms. A total of 178 thermocouple positions were provided of which 63 points were recorded continually.

The $\mathrm{Bi}$ valves in the system were manual-air operated. Gas system valves were either manual or solenoid operated depending on their accessibility.

\section{CONTAMINATION AND RADIATION CONTROL}

\section{Enclosure and Exhaust Air System}

Protection against the spread of fission product or Po contamination due to leakage was provided by a sheet metal enclosure and an air circulating and filtering system. The enclosure seams were sealed with Fiberglas tape. The air inlet and outlet were protected by absolute filters. The outlet was ducted to the suction side of an 800-scfm blower, which maintained the enclosure at a pressure slightly below atmospheric. The flow of air through the enclosure removed the heat generated by the loop. 
The supply of air to the cooler was handled in a similar fashion (see Figure 25) and was discharged through a blower into the enclosure exhaust blower.

Air monitors installed upstream of the cooler and enclosure outlet filters consisted of a counter tube placed over a filter paper disc through which the enclosure or cooler air was drawn. A small air pump was used to circulate the air from the duct through the filter and back into the duct. Count-rate meters with high-alarm provisions completed the system.

\section{In-Pile Section Containment and Monitoring}

As described earlier, the in-pile Bi piping was surrounded by a containment shell. The air space between the piping and the containment was vented to the reactor plenum through an absolute filter and a Kanne ionization chamber. Tubes running through the air space carried cooling air to the tip of the in-pile section in case of overheating. To detect $\mathrm{Bi}$ leaks, these tubes were used to introduce a nitrogen gas sweep to the air space during normal operation. The sweep gas was monitored for a rise in activity in the Kanne chamber. The signal from the chamber was fed to a micromicroammeter with a high-alarm trip. Since an alarm on this unit would indicate $\mathrm{Bi}$ leakage, interlocks were provided to shut down the pump and reactor, and drain the in-pile section. This device and temperature monitoring provided the principal protection against failure from overheating due to nuclear heating in noncirculating $\mathrm{Bi}$ which might be trapped in the in-pile section.

\section{Operation}

\section{OUTGASSING}

After the loop had been assembled and massspectrometer leak-tested, it was outgassed at $500^{\circ} \mathrm{C}$. The system was evacuated at room temperature to its ultimate vacuum, $1 \mu$. The loop was then heated slowly and uniformly to $500^{\circ} \mathrm{C}$ at a rate that prevented the loop pressure from exceeding $50 \mu$. When the outgassing temperature had been reached, pumping on the loop continued until its ultimate vacuum was again reached.

\section{HEAT TREATMENT}

All welds in the system that were to be exposed to the U-Bi fuel were stress-relieved at tempera- tures between $700^{\circ}$ and $735^{\circ} \mathrm{C}$ for a period of $1 \mathrm{hr}$. An attempt was made to stress-relieve by heating the entire loop, with the exception of the pump, to $650^{\circ} \mathrm{C}$ and then raising the weld temperatures to $700^{\circ}$ to $735^{\circ} \mathrm{C}$ for the required hour. This method was successful for $\approx 90 \%$ of the welds, but, because of voids in the insulation and the fact that many larger components acted as heat sinks, the remainder had to be done by wrapping special heater circuits over the weld area. All stress relieving was done under vacuum or an Ar atmosphere.

\section{CHARGING AND DISSOLVING ADDITIVES}

Four Bi charges, each $\approx 1400 \mathrm{lb}$, were prepared for the Radiation Loop. These charges were used for the out-of-pile test, a flushing run, the in-pile run, and a final flushing run. The chemical analysis of the Bi used for the in-pile run is as follows: $\mathrm{Bi}, 99.9995 \%$; Ag, 0.0001\%; Pb, 0.0002\%; Cu, $0.0001 \%$; and $\mathrm{Fe}, 0.0001 \%$.

The $\mathrm{Bi}$, which was received in $25-\mathrm{lb}$ ingots, was cut up into pieces measuring $3 / 4 \times 3 / 4 \times 4$ in. to facilitate loading into a portable melt tank. The pieces were then cleaned with a $10 \% \mathrm{HNO}_{3}$ acid solution and rinsed in distilled water and alcohol. The metal was then charged to the melt tank, melted, and heated to $500^{\circ} \mathrm{C}$ under a pressure of $1 \mu$.

To obtain the desired additive concentrations for the in-pile run and flush charges $(250 \mathrm{ppm} \mathrm{Zr}$ and $350 \mathrm{ppm} \mathrm{Mg}$ ), $159 \mathrm{~g} \mathrm{Zr}$ and $222 \mathrm{~g} \mathrm{Mg}$ were added successively in baskets suspended below the surface of the molten $\mathrm{Bi}$. The $\mathrm{Zr}$, which was added in the form of turnings, was degreased in acetone before addition to the $\mathrm{Bi}$ melt. The $\mathrm{Mg}$, in bar form, was cleaned with $10 \%$ acetic acid. The additive concentrations for the out-of-pile test were 200 ppm $\mathrm{Zr}$ and $325 \mathrm{ppm} \mathrm{Mg}$.

$\mathrm{U}$ additions were made by the same method. The $\mathrm{U}$ was cleaned in $50 \%$ (by volume) nitric acid and then rinsed in distilled water and alcohol.

\section{OUT-OF-PILE TESTING}

Out-of-pile testing of the loop was required in order to condition the loop piping and components, to check the stability of additives in the system, and to determine the operating characteristics of the loop. During this run the in-pile section was set up outside the reactor. 
Prior to starting the loop, additive concentrations were stabilized in the dump tank at $200 \mathrm{ppm} \mathrm{Zr}$ and $325 \mathrm{ppm} \mathrm{Mg}$. The loop was filled on April 29, 1959, and the conditioning runs started. The conditioning consisted of isothermal and $\Delta T$ operation. Temperatures for the isothermal runs were $455^{\circ}$ and $500^{\circ} \mathrm{C}$. A $\Delta T$ of $74^{\circ} \mathrm{C}$ with an in-pile-section exit temperature of $500^{\circ} \mathrm{C}$ was established for the latter test. The operating time at each of these and intermediate temperature conditions was as follows:

A. Isothermal operation

1. $46.9 \mathrm{hr}$ at $455^{\circ} \mathrm{C}$

2. $161.0 \mathrm{hr}$ at $500^{\circ} \mathrm{C}$

3. $13.4 \mathrm{hr}$ at intermediate temperatures

B. $\Delta T$ operation

1. $3.7 \mathrm{hr}$ from isothermal at $500^{\circ} \mathrm{C}$ to a $\Delta T$ of $67^{\circ} \mathrm{C}\left(493^{\circ}-426^{\circ} \mathrm{C}\right)$

2. $6.0 \mathrm{hr}$ at a $\Delta T$ of $67^{\circ} \mathrm{C}\left(493^{\circ}-426^{\circ} \mathrm{C}\right)$

3. $139.5 \mathrm{hr}$ at a $\Delta T$ of $74^{\circ} \mathrm{C}\left(500^{\circ}-426^{\circ} \mathrm{C}\right)$

The average $\mathrm{U}-\mathrm{Bi}$ flow rate during the runs was $2.6 \mathrm{gpm}$. Additive concentrations remained constant throughout the runs.

The loop was dumped and natural $\mathrm{U}$ was added to bring the concentration to $1000 \mathrm{ppm}$. The loop was then operated at the full $\Delta T, 75^{\circ} \mathrm{C}$, for $189 \mathrm{hr}$. At this point it was decided to increase the $\mathrm{U}$ concentration, since sample analysis had indicated that the concentration was remaining constant. The loop was dumped and the procedure was repeated at natural U concentrations of 1200 and $1400 \mathrm{ppm}$. The original specification called for operating the loop at $1400 \mathrm{ppm}$. This was later found to be unnecessary, and the concentration was held at a lower value for the in-pile test. During this period the automatic in-line sampler was installed and successfully tested.

After $1006 \mathrm{hr}$ of operation in a test facility and $868 \mathrm{hr}$ of out-of-pile operation in the Radiation Loop, the pump failed because of failure of the upper bearing. The bearing was replaced and operation was resumed for an additional $95.5 \mathrm{hr}$, when failure of the upper bearing again caused a shutdown. The pump was replaced with a spare unit that had been operated for $1286 \mathrm{hr}$ in the pump test facility. Prior to installation in the loop, this pump had been equipped with totally enclosed bearings and with a 5-bladed impeller, previously described. The pump was operated for $15 \mathrm{hr}$, when the upper bearing again failed.

The pump was removed from the loop, completely disassembled, and equipped with bearings having larger internal clearances and packed with a lubricant suitable for continuous operation at $177^{\circ} \mathrm{C}$. The bearings and lubricant are described in the section on components.

The loop was restarted and operated with the full temperature gradient of $75^{\circ} \mathrm{C}$ for an additional $431 \mathrm{hr}$ without difficulty. It was then dumped and the operating charge was removed. The in-pile test section was also removed, and a new test section, described previously, was installed.

A flushing charge containing $\mathrm{Mg}, \mathrm{Zr}$, and 110 ppm $\mathrm{U}$ was then circulated to dilute any $\mathrm{U}-\mathrm{Bi}$ holdup in the loop and to condition the new in-pile test section by isothermal operation at $505^{\circ} \mathrm{C}$ for $115 \mathrm{hr}$ and $\Delta T$ operation at $75^{\circ} \mathrm{C}$ for $6 \mathrm{hr}$ with the test section held at $500^{\circ} \mathrm{C}$. Because of the lower pressure drop across the new test section, the U-Bi flow rate increased to $5.25 \mathrm{gpm}$. The loop was then shut down after a total of 1531 hr of out-of-pile operation, the flushing charge was removed, and preparations were made for the in-pile test.

\section{IN-PILE RUN}

The 1400-lb in-pile operating charge containing $250 \mathrm{ppm} \mathrm{Zr}$ and $350 \mathrm{ppm} \mathrm{Mg}$ was transferred to the loop from the auxiliary melt tank. A flushing charge was placed in the auxiliary melt tank and kept at $200^{\circ} \mathrm{C}$ for use after the final shutdown or in the event of a loop failure under conditions making it possible to flush the loop before removal of the in-pile section.

In-pile operation of the loop was started on April 23, 1960. As a final check on the equipment, the loop was operated isothermally at $505^{\circ} \mathrm{C}$ for $15 \mathrm{~min}$ before the reactor started up. The velocity through the in-pile test section was $6.1 \mathrm{fps}$. The reactor was then brought to a power level of $13 \mathrm{Mw}$, and the loop was operated isothermally at $455^{\circ} \mathrm{C}$ for $24 \mathrm{hr}$. Additive concentrations during this run were $236 \mathrm{ppm} \mathrm{Zr,} 317 \mathrm{ppm} \mathrm{Mg}$, and $35 \mathrm{ppm}$ natural $U$. After radiation surveys of the area had indicated that the loop was adequately shielded, the loop was dumped and a sufficient amount $(9 \mathrm{~g})$ of $93 \% \mathrm{U}^{235}$ was added to the melt and dump tank to raise the $\mathrm{U}$ concentration $14 \mathrm{ppm}$. After the $\mathrm{U}$ concentration had been verified by sampling, the loop was filled and operated isothermally at $455^{\circ} \mathrm{C}$ for $46 \mathrm{hr}$ as a further check on the shielding. At this time numerous neutron and gamma leaks became apparent which were corrected by using con- 
crete and Masonite. The shielding was further tested at total U concentrations of 170 and $450 \mathrm{ppm}$. During this period the loop was operated for a total of $101 \mathrm{hr}$.

At the completion of the shielding tests, the $U$ concentration was increased to $1036 \mathrm{ppm}$ (931

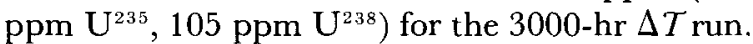
The $\mathrm{Zr}$ and $\mathrm{Mg}$ concentrations remained constant at 245 and $350 \mathrm{ppm}$ respectively throughout the shielding tests. The loop was filled and the temperature gradient of $75^{\circ} \mathrm{C}$, with the in-pile test section at $500^{\circ} \mathrm{C}$, was established on June 9, 1960. With the reactor operating at $17 \mathrm{Mw}$, the amount of fission heat generated was measured as $2.02 \mathrm{kw}$. The gamma heating was measured as $0.871 \mathrm{kw}$ or 126 $\mathrm{mw} / \mathrm{g}$ steel.

Operation of the loop was normal until July 7 when, after $513 \mathrm{hr}$ of $\Delta \mathcal{T}$ operation, the automatic in-line sampler failed because $\mathrm{Bi}$ was being blown up into the ball valve separating the sampler from the loop proper. Since repair of the sampler was found to be impractical, it was decided to dump the loop every two weeks during routine reactor shutdowns and sample from the melt and dump tank. This procedure was followed without difficulty for the remainder of the run.

The operating characteristics of the loop, namely $\mathrm{Bi}$ velocity, furnace input power, pump current, and deposition gauge readings, remained constant throughout the run.

The loop was voluntarily shut down at $1700 \mathrm{hr}$ on November 17, 1960, after operating in-pile for a total of $3409 \mathrm{hr}$. Of this total $3048 \mathrm{hr}$ were at a $\Delta T$ of $75^{\circ} \mathrm{C}$ with the reactor power level between 15 and $20 \mathrm{Mw}$.

Prior to removing the in-pile section from the reactor, the operating charge was transferred to the cold disposal tank while the reactor was shut down. A flushing charge of Bi containing $424 \mathrm{ppm}$ $\mathrm{Mg}$ and $298 \mathrm{ppm} \mathrm{Zr}$ was then circulated for $0.5 \mathrm{hr}$ to dilute any $\mathrm{U}$ and fission product hang-up in the loop.

\section{In-Pile Section Removal and Transfer}

On completion of the in-pile run it was necessary to remove the in-pile section from the reactor and transport it to the metallurgical hot cell in the Hot Laboratory. It was necessary to design a handling system adequate for safe performance of the maneuver at the high radiation levels expected under the most unfavorable shutdown conditions.

Three shutdown conditions were considered. The most favorable condition would occur if the active $\mathrm{Bi}$ charge could be dumped and the loop flushed by circulating a clean $\mathrm{Bi}$ charge. In this case the radiation levels would be due to activation of the in-pile section materials and the associated activity from residual fission products. The second case would occur if the shutdown conditions of the loop prevented flushing and draining of the in-pile section. A third situation would result if the loop were shut down with a plugged inpile section and the reactor could not be shut down for the major part of the normal two-week reactor cycle. The stagnant U-Bi charge would be subjected to continuous irradiation during this period instead of the normal cyclic irradiation under flow conditions. Radiation levels were calculated to be at least $5 \mathrm{r} / \mathrm{hr}$ for the first case and $\approx 20 \mathrm{r} / \mathrm{hr}$ and $100 \mathrm{r} / \mathrm{hr}$ for the second and third cases, respectively, when measured at $6 \mathrm{ft}$ from the side of the inpile section.

The removal and transport system was designed to handle the most extreme case. It was based on the use of an unshielded coffin to receive the in-pile section as it was pulled from the reactor and to carry it to the Hot Laboratory, with distance and time serving to minimize personnel exposures.

A monorail, extending from the pile face to the hot cell preparation room, was constructed. The coffin was suspended from this and ropes were tied to both ends for pulling and braking. Figure 26 shows the coffin and in-pile section. The coffin was constructed of a steel frame and bottom, $\mathrm{Al}$ side and top panels, and a Lucite side wall for viewing. A sheet-metal bottom pan was provided to permit free movement of the in-pile section during insertion. Since the in-pile section had to be level for removal of the inner bundle in the hot cell, a number of extendable support yokes were incorporated in the coffin. These yokes were manipulated by ropes attached to lever-operators on the side of the unit.

The shielding, containment, insulation, and piping at the pile face were removed after shutdown. A remotely operated Manco guillotine rod cutter was used to cut the piping and service lines. Figures 27 and 28 show the pile face area before and after the cutting operation. The coffin was brought up to 


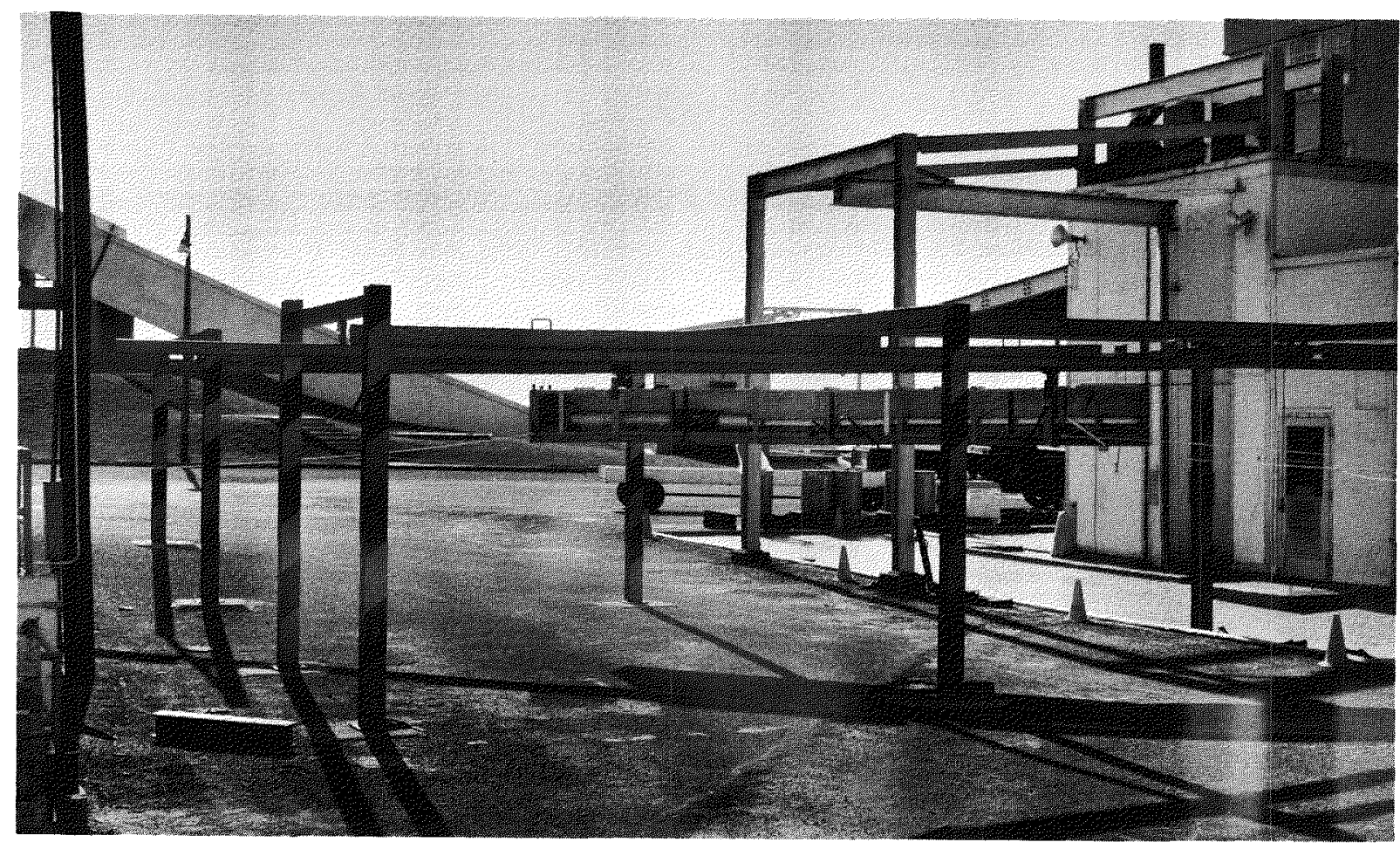

Figure 26. In-pile section removal utilizing monorail.

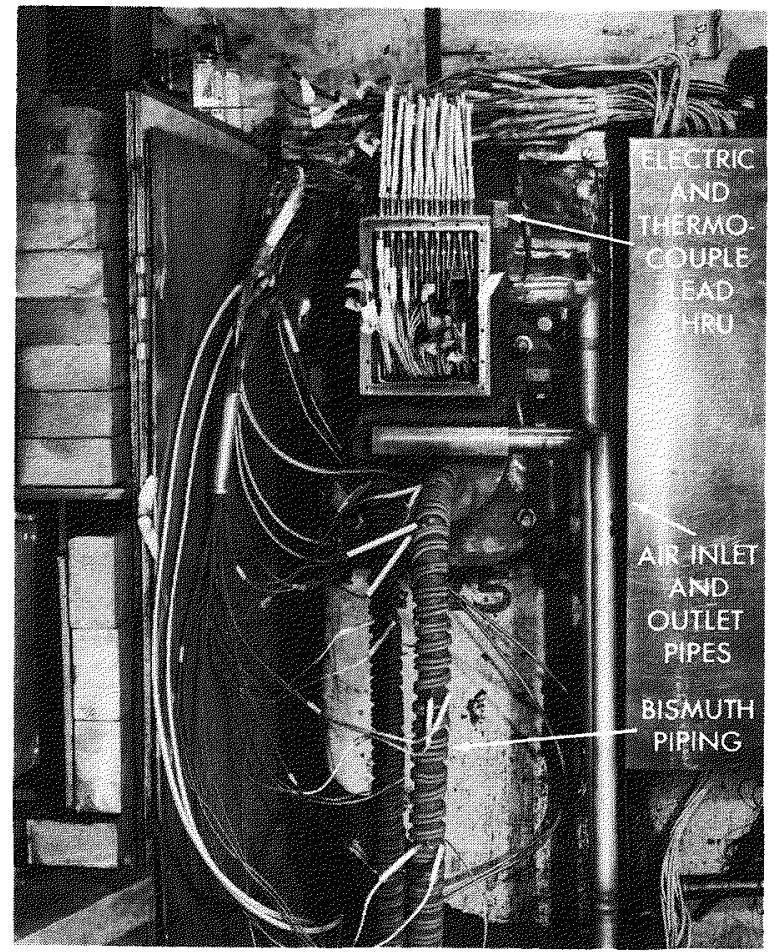

Figure 27. Pile face area during installation.

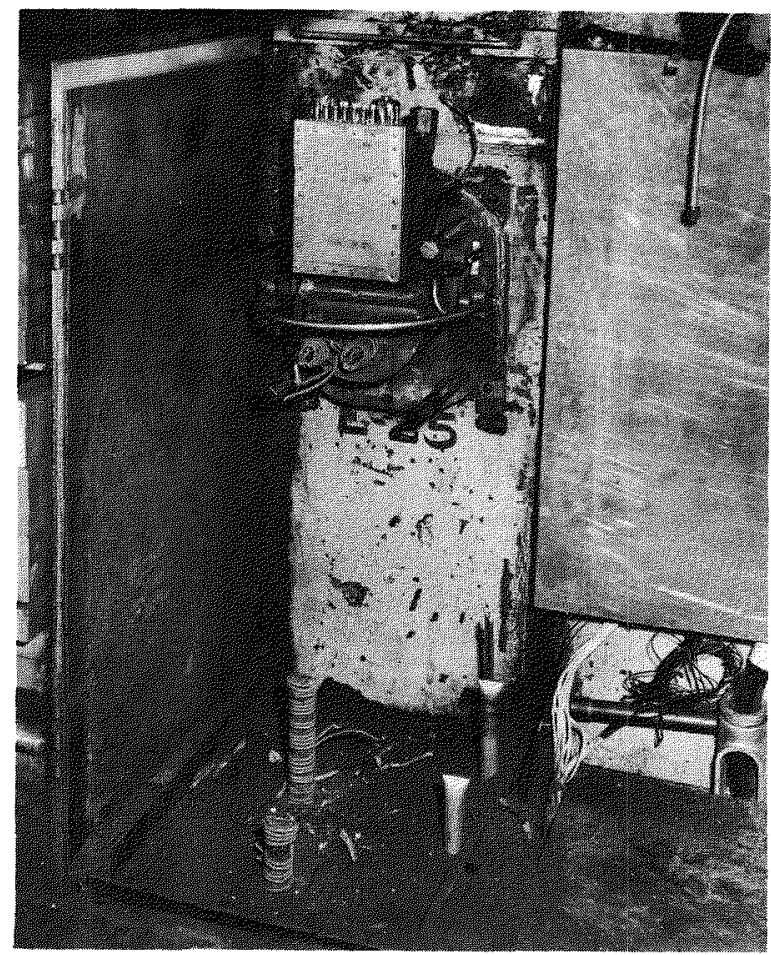

Figure 28. Pile face area - In-pile section cut free. 
the pile face, and the necessary operator shields and pulling and yoke-operating lines were installed. Personnel were stationed as follows: close to the pile face behind shielding to direct the pull, $40 \mathrm{ft}$ in front of the pile face to pull the section out of the reactor and operate the yoke ropes, at a shielded side position to operate the snubbing rope, and at the metallurgical hot cell to pull the coffin across the pile yard and into the cell. In the hot cell the piping bundle was withdrawn from its outer containment shell (which was left in the coffin) and cut into short lengths for storage and handling in the hot cell proper. Following this, the coffin and containment shell were disposed of and the hot cell door was closed.

One difficulty was encountered. At the start of the pull, the in-pile section bound on a shield plug installed in the pile hole. When greater pulling force was applied, the plug overrode its holding wedges and came out with the in-pile section. The plug's location on the section prevented the use of some of the leveling yokes, but a sufficient number were available to do the job. This contingency had been considered in the design of the equipment, and it was known that the difficulty with the plug could be overcome, although the extent of the complications could only be surmised prior to removal.

The entire procedure, from the removal of the shielding and cutting of pipe to the final cutting of the in-pile section in the Hot Laboratory, took six days, during which the maximum radiation exposure to personnel was $245 \mathrm{mr}$. Seventeen men were involved, and the average exposure per man was $80 \mathrm{mr}$.

\section{Out-of-Pile Section Removal}

The size and complexity of the loop section outside the pile required its dismantling on a component basis. Since the removal of this equipment could be paced to permit safe radiation practices, a direct working approach seemed possible. If radiation levels proved too high for this approach, a semiremote technique was to be used, with tools adapted for this purpose.

In practice, the radiation fields encountered were not severe and a reasonably direct approach was used. The loop piping read up to $10 \mathrm{r} / \mathrm{hr}$ on contact. At the enclosure walls, fields varied from 200 to $1000 \mathrm{mr} / \mathrm{hr}$ but dropped off rapidly with distance, so that $1 / 4$ and $1 / 2$-in. thicknesses of lead sheet furnished adequate shielding.

All piping cuts were made with a Manco guillotine rod cutter suspended from an electric hoist. To minimize the spread of contamination special cutting techniques were developed. Before each cut, the cutting jaws of the guillotine were replaced with crushing jaws which flattened the pipe in the cutting region. A damp cloth was supported under the pipe to be cut. Cutting blades were installed in the guillotine cutter, the cutter was lowered into position on the pipe, and the cut was made. After a pipe section was freed from the loop, the damp cloth was folded around it and the piece was removed to a shielded cask.

The large components, such as the heat exchanger and furnace section, were cut free and removed in a wooden coffin. The pump, in its containment, was cut free and removed with a fork lift. Both dump tanks were raised from their pit in the floor into a cylindrical shield in which they were transported.

Radiation doses to the three men involved directly in the removal work did not exceed $50 \%$ of the allowable limit. Contamination control was accomplished with the techniques normally used at the reactor, including exclusion areas where rubbers were worn and left, removal of contaminated equipment from the area in plastic bags, the use of respirators, and frequent personnel and area surveys. The presence of Po in the Bi was sufficient incentive for close observation of contamination control methods. Alpha contamination was observed after some pipe cuts, but in all cases it was cleaned up readily by wiping with damp cloths and mopping. Floor areas were mopped after each operation and clean-up. As was the case with the previous $\mathrm{Bi}$ in-pile loop operated at Brookhaven, ${ }^{3}$ the $\mathrm{Po}$ (when associated with $\mathrm{Bi}$ ) does not seem to spread through an area, cling to equipment, or become air-borne to a dangerous extent.

\section{In-Pile Section Disassembly}

The BNL metallurgy hot cell was constructed and equipped to handle alpha-contaminated material, and no extensive modification of the cell was necessary to section the loop. However, the contamination control area (isolation room), where the coffin was located during disassembling operation, was only partially shielded, and temporary 

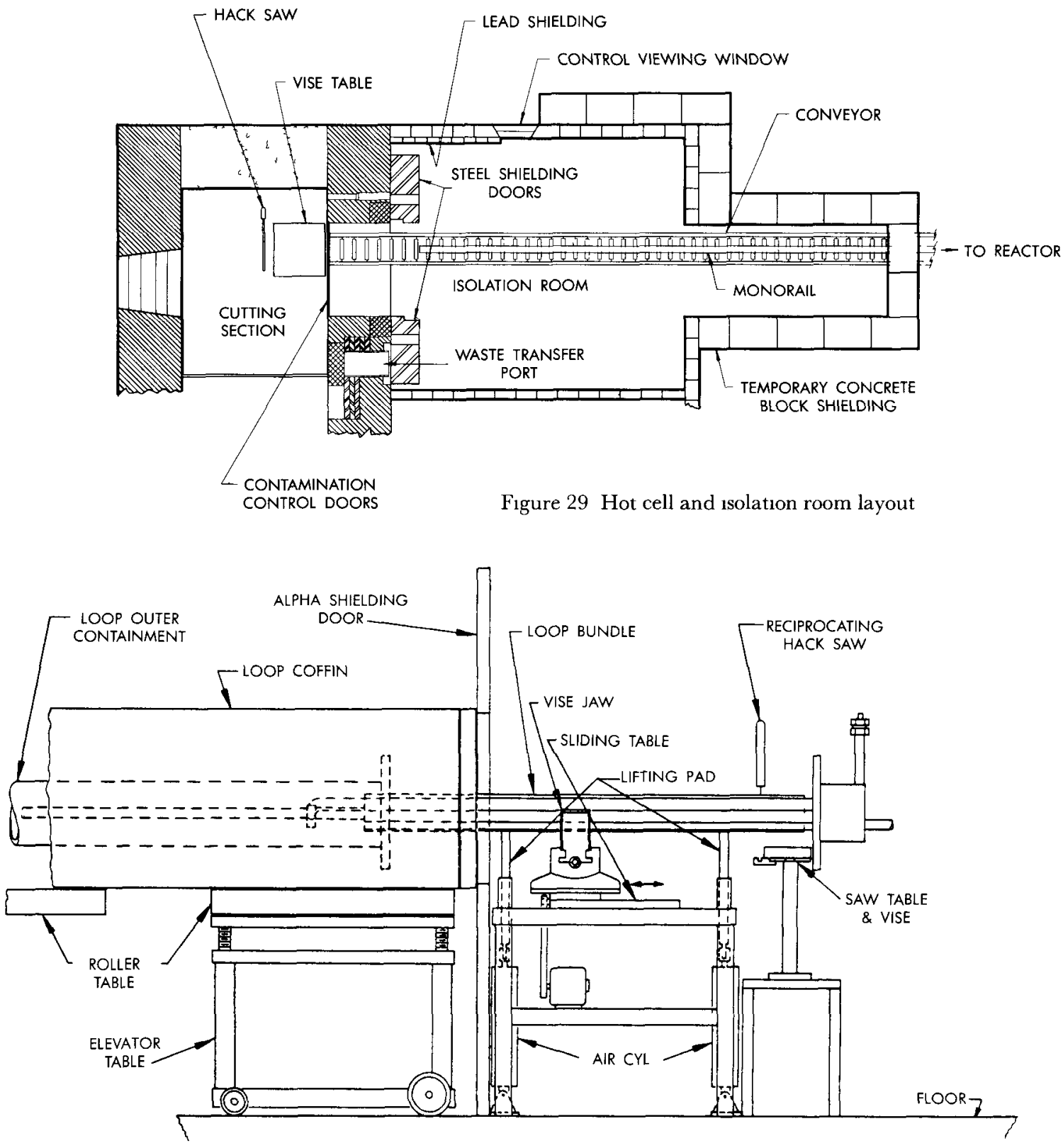

Figure 30 Cutoff vise and saw

shielding was set up to protect the operating personnel. Figure 29 shows the general layout of the cutting cell and the isolation room

The coffin was transported from the reactor to the rear of the hot cell by overhead monoral. In the isolation room, it was set on a table by elevating two sections of the roller conveyor to support the coffin which was then released from the monorail by pulling two hanger pins A General Mills Model \#100 arm mounted on a bridge crane was used to open the door of the coffin and roll the coffin up to the cutting cell.

Figure 30 shows schematically the layout in the cutting cell for advancing and sawing the loop The initial pull was done with the cell's 1-ton crane. Subsequent advancing was done with a special vise mounted on a sliding table. The vise could also be moved in a vertical direction to position the loop for cutting. Figure 31 is an assembly drawing of this vise, which had a horizontal travel 


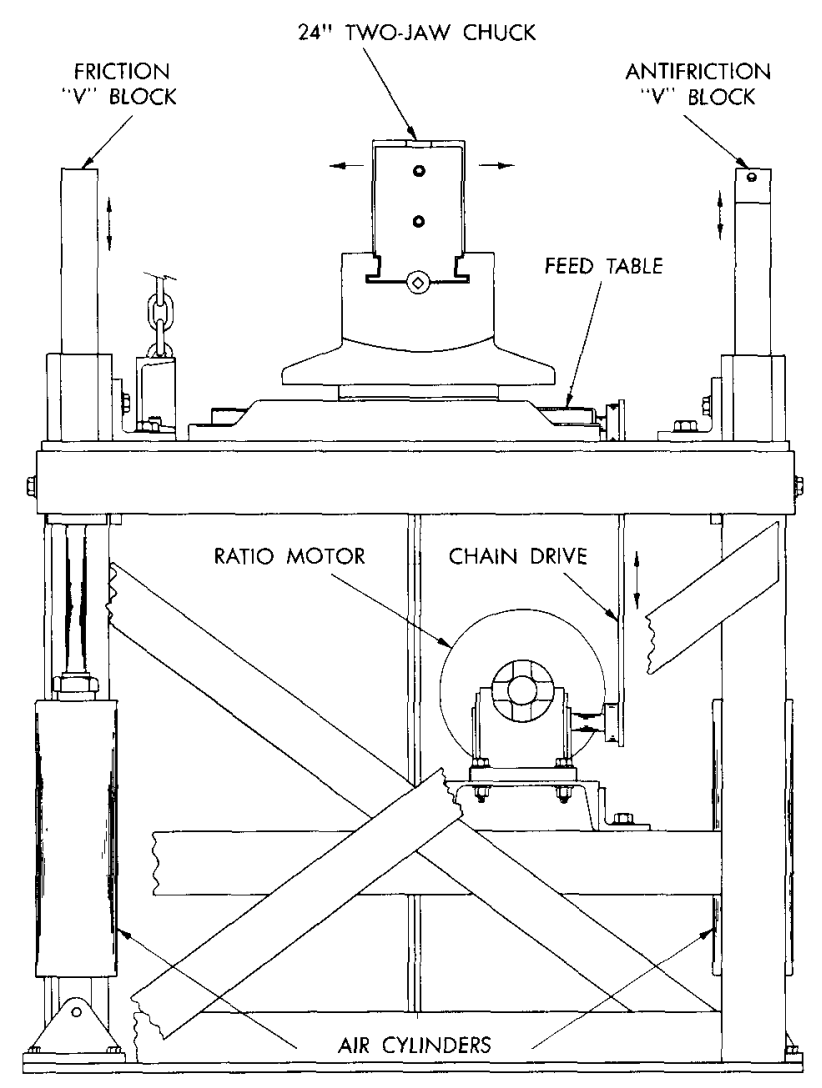

Figure 31. Vise table.

of 8 in. and jaws designed to grip the loop bundle and exert a 500-lb pull. Cutting was done with a simple reciprocating hacksaw, modified to make blades easily interchangeable and to provide a wide opening to allow the flange to pass through. Manipulation in the cell was performed with a Lee Associates arm mounted on a jib boom, a pair of Model 8 manipulators, and a bridge crane.

In the cell the bolts joining the loop flange and the containment flange were removed with the Lee Associates arm, the pulling cable was attached to the yoke, and separation of the loop from the containment was begun. Difficulties were encountered during the first pull when the loop containment rolled clockwise about $30^{\circ}$, and the Conax fittings for power and thermocouple wires could not clear the coffin opening. The problem had been anticipated and methods had been worked out to turn the loop; however, because of the added weight of the pile-hole shielding plug that came out with the containment, considerable improvisation was needed to complete the first pull.
Figure 32 shows the hacksaw in action and the first cut being made. A portable hacksaw (Figure 33) was placed in the cell as an alternative method of cutting in case the large hacksaw failed. Two successful cuts were made, but during the third cut the pin holding the blade sheared and had to be replaced remotely. The original pin had been replaced during the modification of the saw but was not properly hardened. Repeated shearing occurred with subsequent pins because they were fabricated as needed and were not heat treated, which considerably increased the time required to disassemble the loop. After the large-diameter holdup tank was cut, the remainder of the in-pile section was sawed with the portable hacksaw. The total time required to disassemble the loop was 15 hr.

After the cutting operation was completed, the coffin was rolled back and the gamma door was closed. A man had to enter the isolation room to reinsert the door of the coffin, since remote operation proved unsuccessful. Entering was relatively safe since no alpha contamination was found in the isolation room after the cutting operation. The coffin was then pulled onto the "white elephant" disposal trailer and taken to the disposal area. The dosage received by each of the five persons associated with the hot cell operation was $\approx 100 \mathrm{mr}$. Most of the exposure was received in the normal operation of loading the coffin into the trailer.

Contamination control throughout the entire operation was excellent. No alpha contamination was found outside the cutting cell. The control of alpha contamination was attributed to complete drainage of the $\mathbf{U}-\mathrm{Bi}$ from the loop and subsequent flushing with clean $\mathrm{Bi}$. Also, the $\mathrm{Po}^{210}$ was well tied up with the Bi. Smears taken inside the cell immediately after cutting indicated that $\approx 3 \%$ of the activity was from alpha particles. The alpha activity of the loop fluid was $4 \times 10^{7} \mathrm{dis} / \mathrm{min} / \mathrm{g} \mathrm{Bi}$. The alpha activity of the smears taken from the cell was $4.8 \times 10^{3} \mathrm{dis} / \mathrm{min}$, which indicated the effectiveness of the flushing operation.

Because of the possibility of alpha contamination, all waste regardless of gamma activity was disposed of through the cell waste disposal port, bagged in polyethylene, and removed from the cell in a disposal pig. The flange, which was too large to pass through the disposal port, was removed when the cell door was opened for decontamination of the cell. 


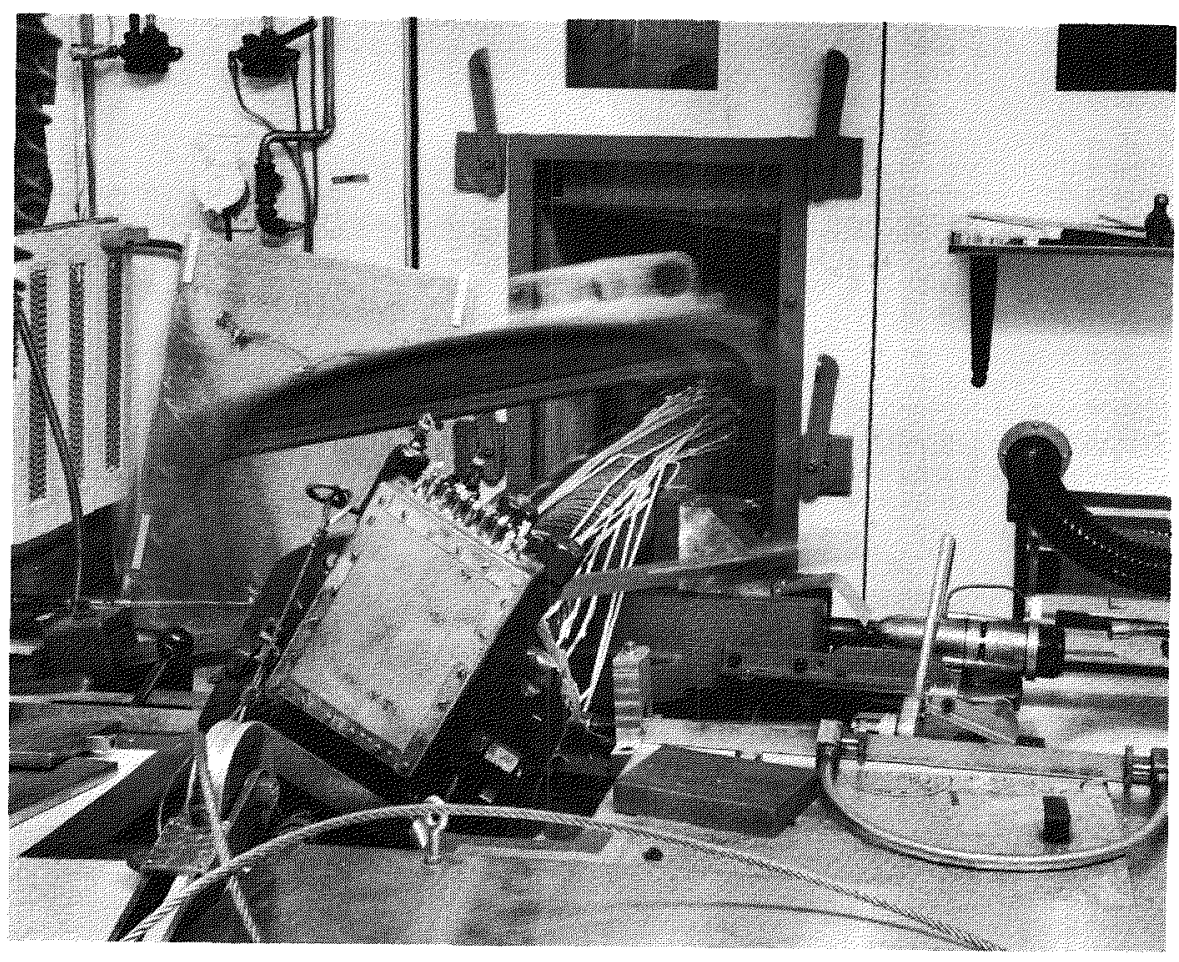

Figure 32. Cutting of in-pile section.

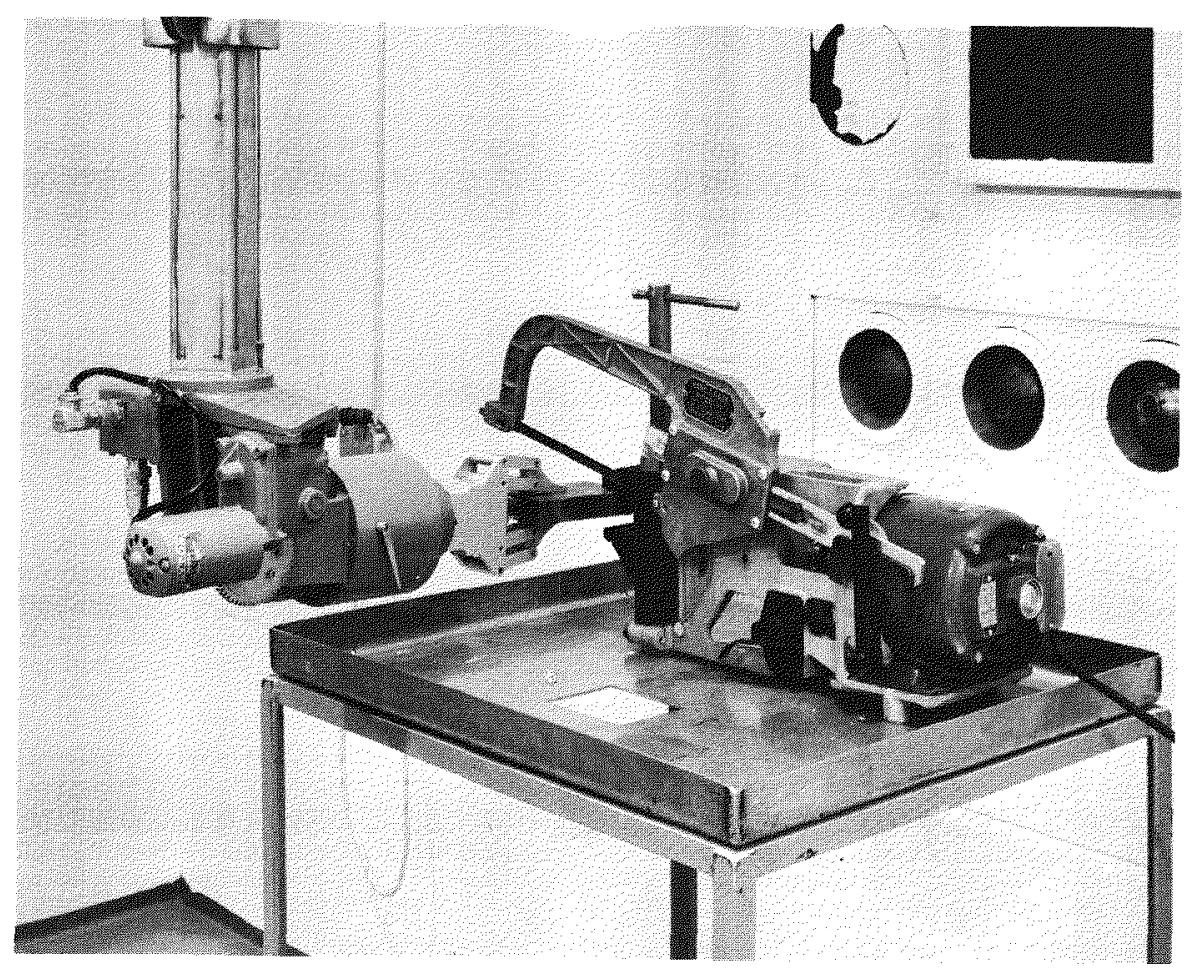

Figure 33. Portable hacksaw. 


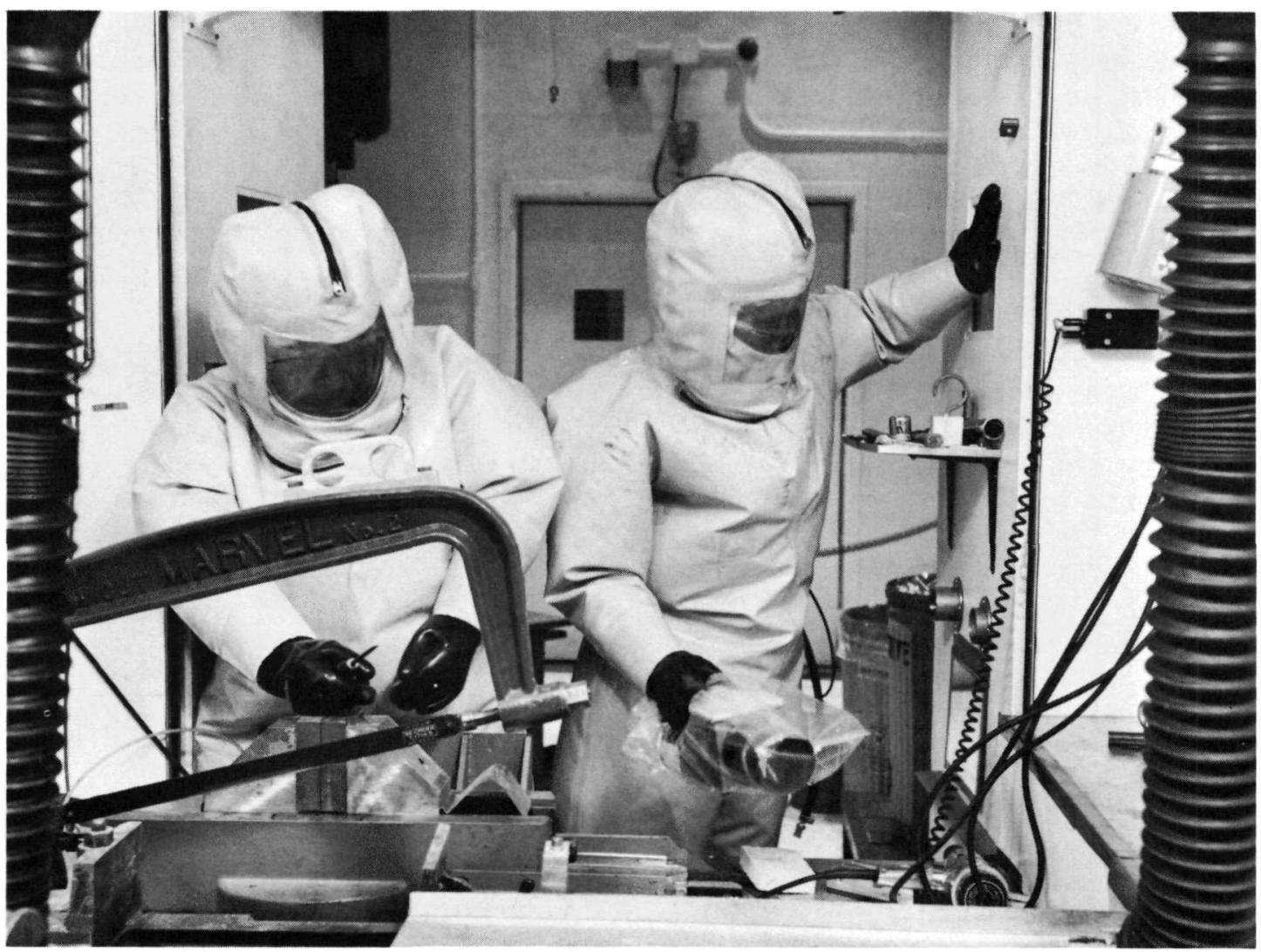

Figure 34. Hot cell decontamination.

Cell decontamination was done by remote vacuum cleaning, which lowered the gamma activity to $1 \mathrm{r} / \mathrm{hr}$ at the back entrance of the cell. The remaining activity was imbedded in the vise, and subsequent cleaning had to be done within the cell by personnel dressed in decontamination suits with breathing air supplied through an air-demand regulator (Figure 34 ). Two men working for $\approx 2$ hr were able to lower the activity to the 50 to 100 $\mathrm{mr} / \mathrm{hr}$ level and the alpha activity on smears to a few dis/min. Thereafter, cell cleanup and setup for the next phase of loop examination continued with the operators dressed in coveralls and equipped with dust masks.

\section{Results}

\section{EXAMINATION OF CORROSION TEST SPECIMENS}

The following pieces of the loop were saved for metallographic examination:
1. The test section located at the innermost portion of the in-pile section at the region of highest temperature and highest flux. This test section is shown in detail in Figures $8,9,10,11$, and 12 .

2. The containment pipe section housing the test section of item 1 .

3. The test section located in the holdup tank in the region of high temperature and low flux.

4. A section of the deposition gauge where the lowest temperatures of the system was attained (see Figure 15).

Item 1 was studied in detail. A transverse metallographic section was made of each of the metal and graphite stringer specimens. The test section was photographed before cleaning with $\mathrm{Hg}$ to show the degree of $\mathrm{Bi}$ wetting. Then the tubular specimen was sectioned transversely between each transverse weld. Each of these sections was cut longitudinally to examine the inside surfaces. Each piece was examined before and after $\mathrm{Hg}$ cleaning. 
Four transverse metallographic sections were prepared for each test specimen, two at the unbored portion and two at the bored end. Two sections at each end were required so that each of the two longitudinal welds could be examined. One longitudinal metallographic section of each transverse weld was prepared. A total of 46 metallographic samples were prepared of the test section and the stringer.

Item 2, the outer pipe, was sectioned longitudinally and examined at low power.

Item 3, the holdup tank section, was examined only at low power in the condition in which it was removed from the loop. The tensile and impact
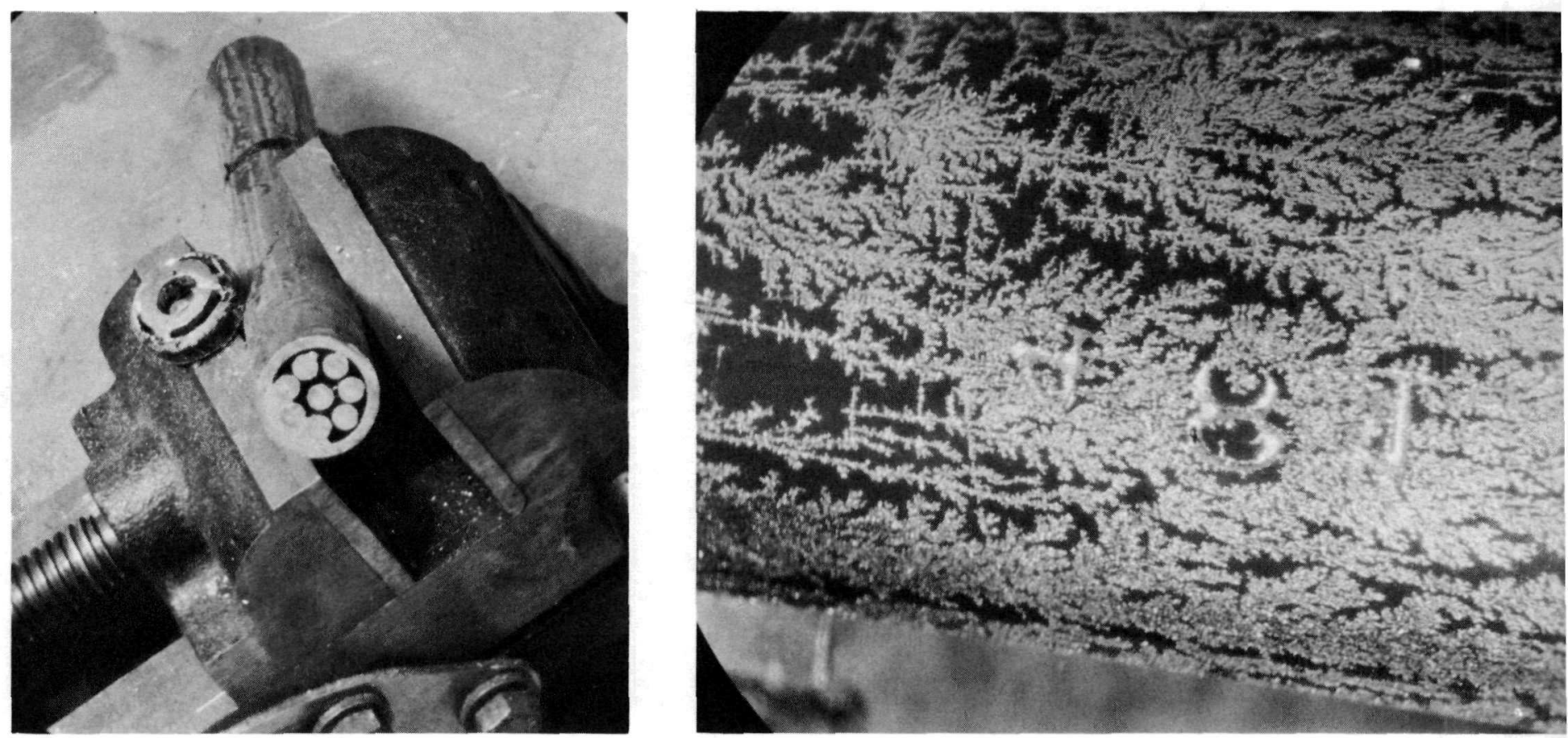

Figure 35. Holdup tank test sectionLow power examination. specimens inside this section were not extracted from inside the test section for examination.

Item 4 , a section of the deposition gauge $\approx 6$ in. long, was sectioned to examine the inside surfaces for Fe deposition.

\section{Low Power Examination}

Low power examination using the remote Kollmorgen periscope $(4 \times)$ and B \& L stereomicroscope (up to $30 \times$ ) was made on the test sections as removed from the loop and after $\mathrm{Hg}$ cleaning. This examination indicated that surfaces in contact with the U-Bi were only partially wetted, and no evidence of corrosion pitting was found.
Figure 37. In-pile test section, specimen No. $481,4 \times$.

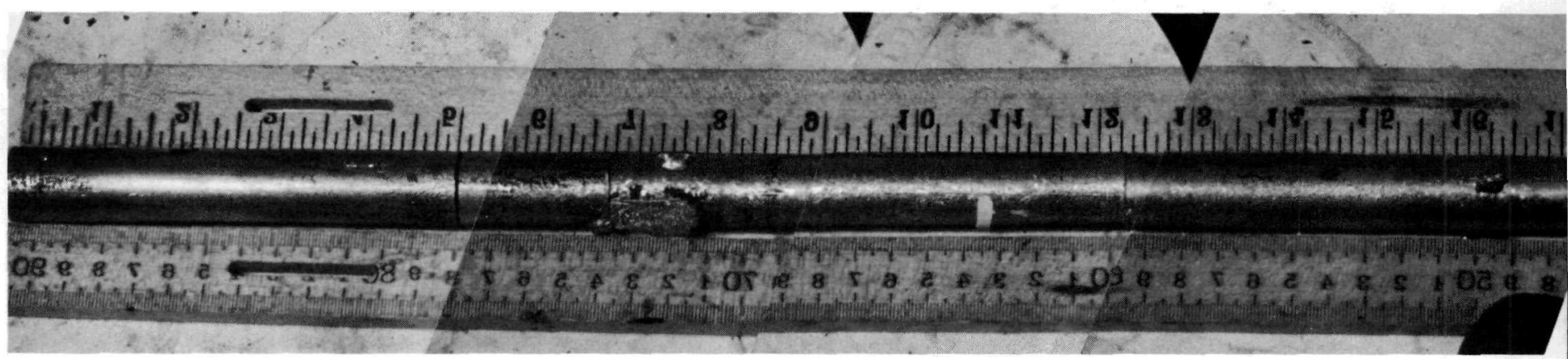

Figure 36. In-pile test section, outer surface - Low power examination. 
Figure 35 shows the holdup tank test section, and Figure 36 shows the outer surface of the in-pile test section; note that incomplete wetting is indicated in both figures. Figure 37 shows specimen No. 481 (carbon steel, Si-killed) of the in-pile test section at about $4 \times$. This was quite typical of all the test specimens. Figure 38 shows at $4 \times$ some of the metal and graphite samples from the stringer located inside the test section. Figures 39 and 40 are typical, respectively, of the inside surface of a test piece and a transverse weld after $\mathrm{Hg}$ cleaning.

Examination of the sectioned deposition gauge indicated no precipitation build-up. Figure 41 shows at $4 \times$ the inside surface immediately downstream from the gauge lugs. $\mathrm{Hg}$ cleaning removed all the surface layer, and it was concluded that no
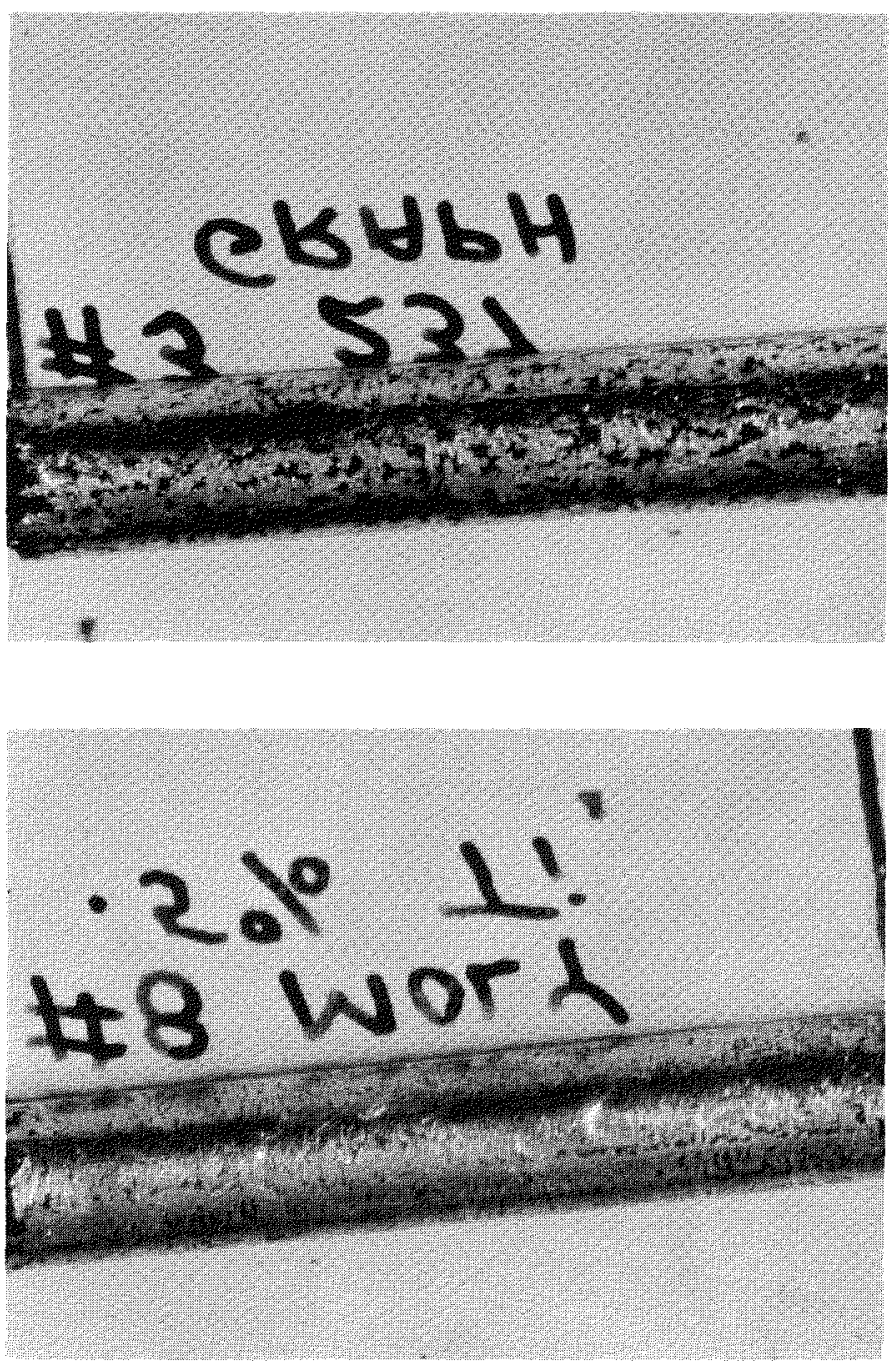

deposition had taken place in this area and $\approx 6$ in. downstream from this area. As can be seen in Figure 41 , the machining of the inside surface was exceedingly rough.

\section{Metallographic Examination}

Metallographic examination of the graphite specimens on the stringer indicated that the graphites Graphitite $\mathrm{G}$ and EY9 are impermeable to $\mathrm{U}-\mathrm{Bi}$, while the other specimens showed varying degrees of permeability. Figures 42 and 43 , respectively, show at $75 \times$ what is regarded as light and heavy penetration. The results are summarized in Table 3. Some of the graphite samples were mechanically damaged in the remote cutting and mounting operation. However, no damage to
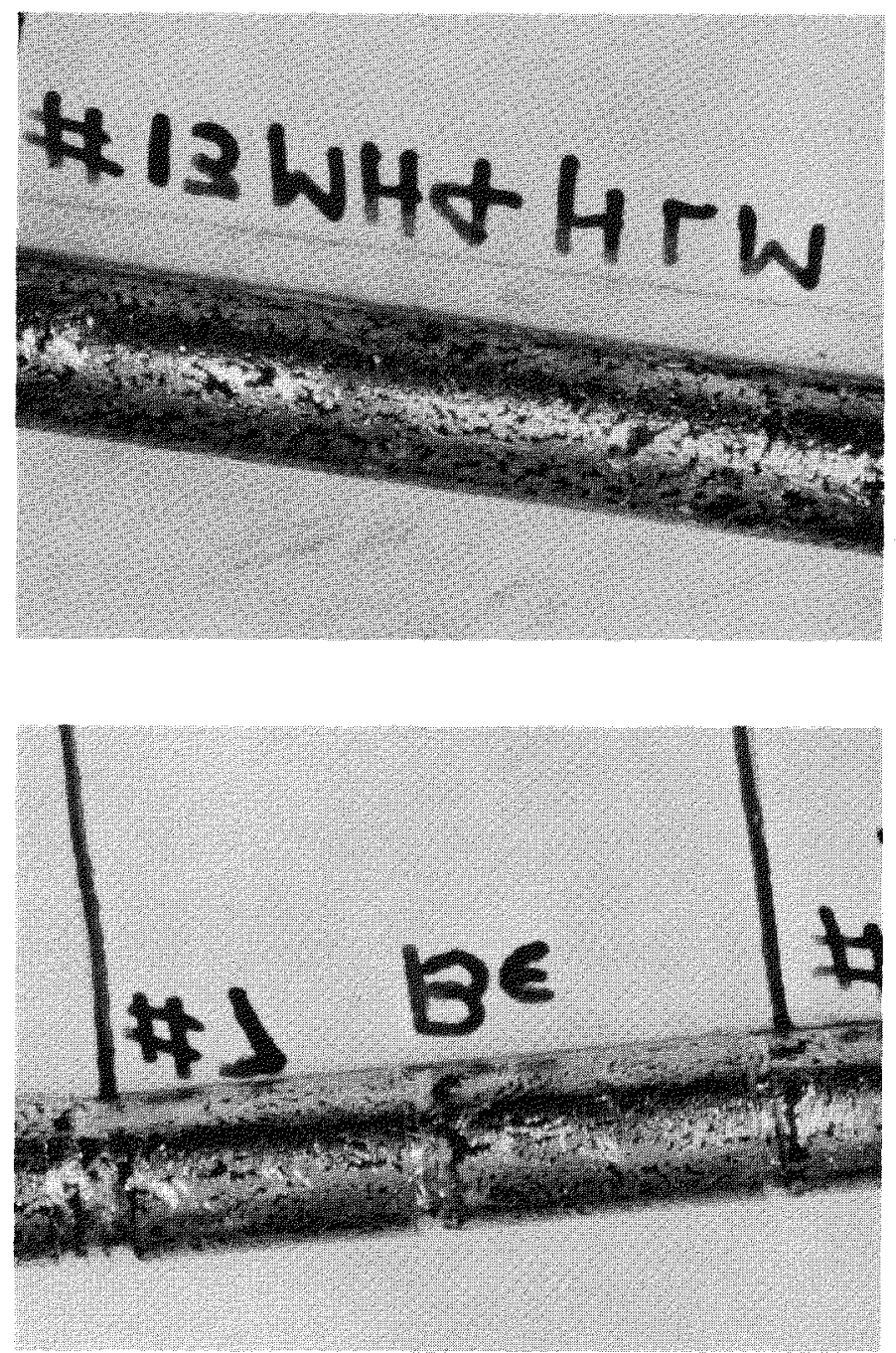

Figure 38. In-pile test section, graphite and metal stringer samples, $4 \times$. 
Table 3

Penetration of U-B 1 in Graphite

\begin{tabular}{ll}
\hline Graphite specimen & Degree of U-Bi penetration \\
\hline MH4HLM \#1 & Heavy \\
237 & Specimen crushed in mounting \\
CEY & Specimen broke in cutting \\
G & None \\
R0020 & Heavy \\
EY9 & None \\
R0025 & Slight \\
A & Heavy \\
R-4 & Slight to moderate \\
MH4HLM \#2 & Heavy \\
ATL82 & Moderate \\
\hline
\end{tabular}

graphite attributable to neutrons or fission fragments was observed.

The metal samples (Mo, Mo-1/2\% Ti, Ta, and Be) show no evidence of corrosion. Some surface pittung was observed on the outer surface of the pure Mo sample. The largest pit found (Figure 44, a micrograph at $300 \times$ ) has a depth of $\approx 0.005$ in The pit does not have the appearance of a corrosion pit, and no other pit with this depth was found after repeated regrinding and repolishing. On the other hand, the indentation is believed not to be from mechanical wear because no evidence of flow metal was found Since no standard sample of the original condition of the surface was available for comparison, interpretation of this surface imperfection was exceedingly difficult An estumate of a cavitation parameter for this region indicates that cavitation may have existed and caused pitting of the Mo, the softest material in the loop.

No evidence of corrosion was found in 46 cross sections ( 4 from each specimen and 1 from each transverse weld) of the test section examined. However, a sizable imperfectıon $\approx 0006 \mathrm{in}$ deep and $3 / 16$ in. long was found on the outside surface of specimen No 484 (21/4\% Cr-1\% Mo, normalized and tempered). This pit is shown in Figure 45 at $150 \times$ Numerous other pits, shallower in depth but with the same peculiar shape, were on this specimen and on specimen No $483(1 / 2 \%$ Cr $-1 / 2 \%$ Mo) It was finally concluded that these are not corrosion pits but mechanical imperfections made by the jaws of either a vise or pliers No evidence of flow metal was found at the pit, but it was concluded that subsequent stress relieving after fab-

Figure 46 Shallow pit at surface of specimen No 483, $1 / 2 \% \mathrm{Cr}-1 \%$ Mo, similar in shape to that shown in Figure $45,100 \times$

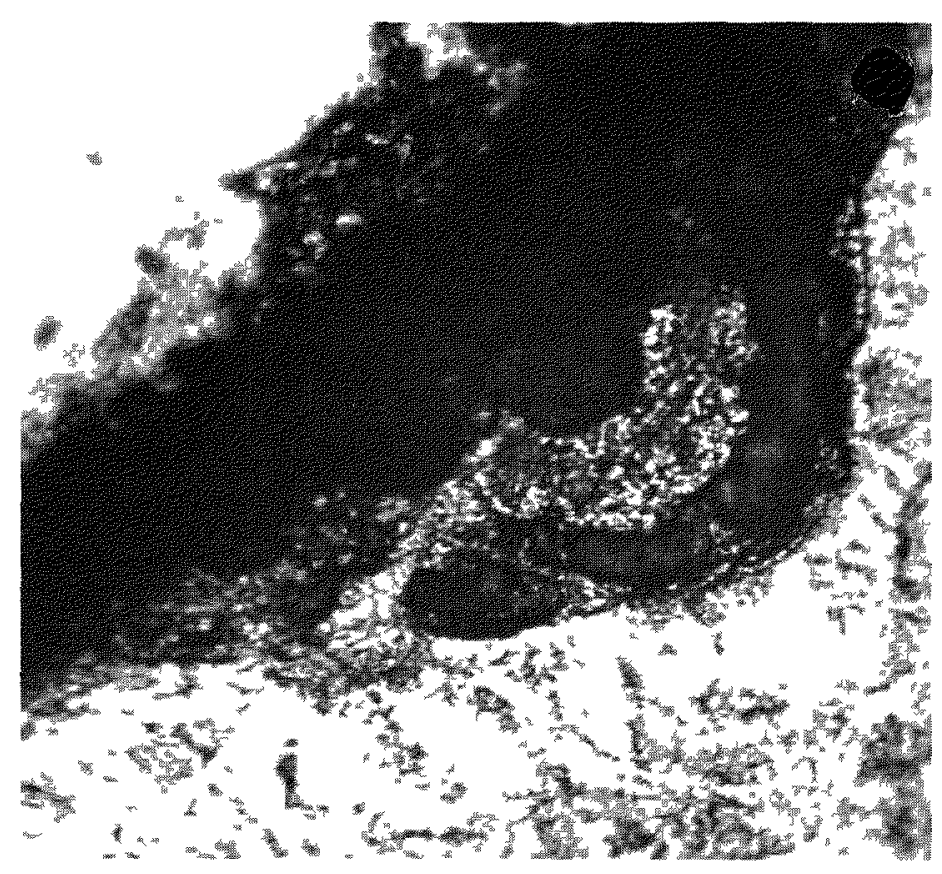

Figure 44 Pit, molybdenum stringer sample, $300 \times$

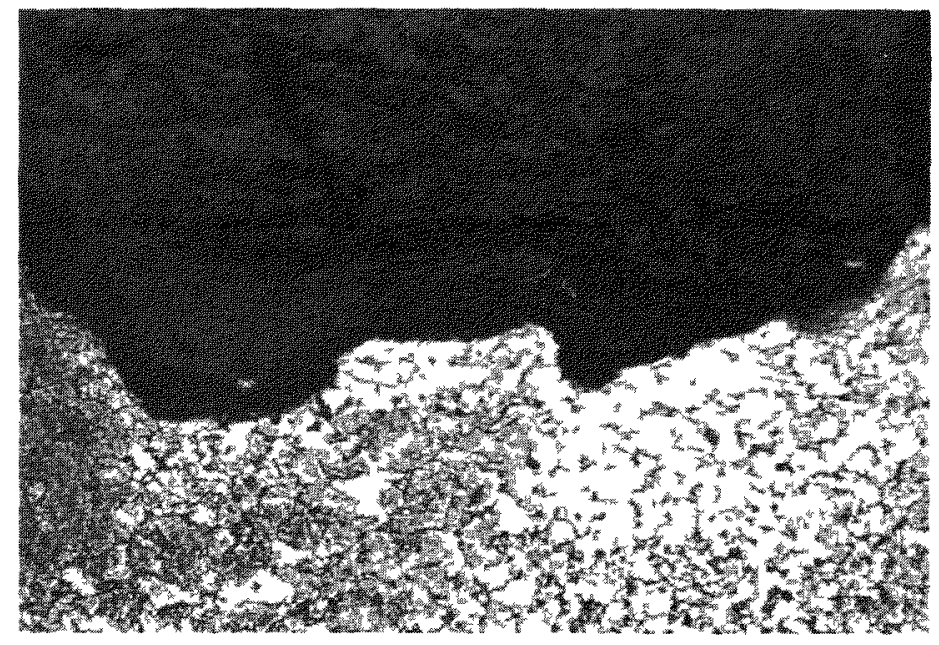

Figure 45 Pit at surface of specimen No 484, $21 / 4 \%$ Cr-1\% Mo, etched in nital, $150 \times$

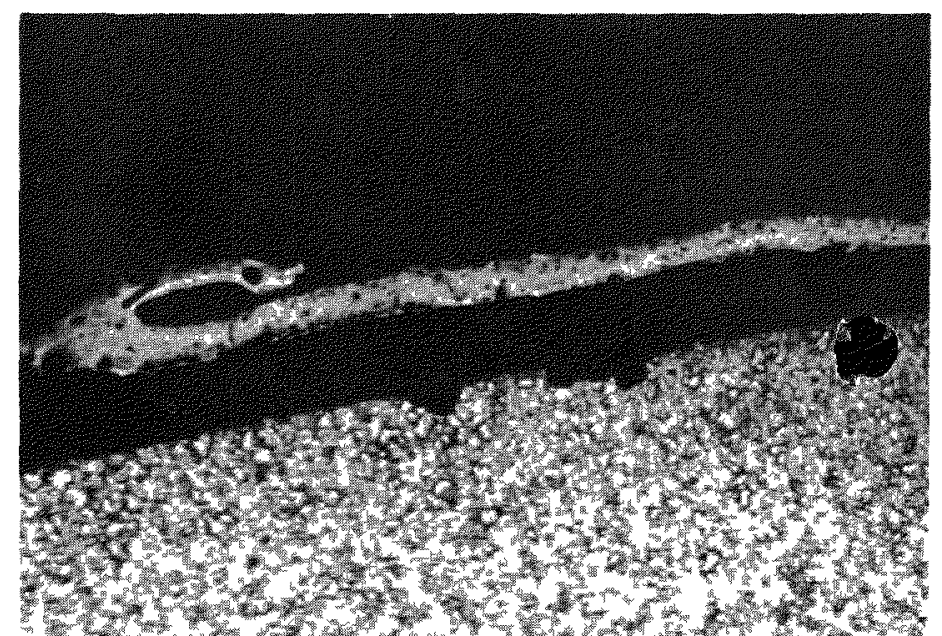


rication had removed the flow markings. A shallow pit showing the same shape is shown in Figure 46 , which is a $100 \times$ micrograph of the outer surface of specimen No. 483. Because the entire test section was machined after welding, no standard sample was available for comparison. The lack of such a sample made the interpretation of these small surface imperfections difficult.

Throughout the metallographic examination no change in microstructure was observed. Although no quantitative measurement was taken, decarburization was not noticeable in any of the steels. Figure 47 shows the heat-affected zone of the longitudinal weld of specimen No. $487\left(2 \frac{1 / 4}{4} \mathrm{Cr}-1 \%\right.$ $\mathrm{Mo})$. Note that no change of the martensitic structure is apparent.

\section{CORROSION PRODUCT ANALYSIS}

Corrosion product analysis of U-Bi samples taken from the melt and dump tank and from the flowing stream indicated no detectable increase over the entire operating period. $\mathrm{Fe}, \mathrm{Cr}$, and $\mathrm{Ni}$ remained less than $10 \mathrm{ppm}$, and $\mathrm{Mn}$ and Mo were not detectable (limit of detection, $10 \mathrm{ppm}$ ).

\section{ADDITIVE STABILITY}

Maintaining additive concentrations was not a problem in the Radiation Loop. Prior to filling the loop for the in-pile run, $\mathrm{U}, \mathrm{Mg}$, and $\mathrm{Zr}$ concentrations were stabilized in the melt tank. Material balances for $\mathrm{Zr}, \mathrm{Mg}$, and U were 96, 101, and $102 \%$ respectively. For the 1000 -ppm U concentration run, additive concentrations of $\mathrm{U}^{238}$, $\mathrm{U}^{235}, \mathrm{Mg}$, and $\mathrm{Zr}$ in the melt tank were 105,931 , 350 , and $245 \mathrm{ppm}$ respectively. After an initial decrease in $\mathrm{U}$ concentration due to the dilution of the charge with the Bi hang-up in the loop, the additive concentrations remained constant throughout the run (Figure 48). The average analysis in ppm of 58 samples taken from the loop during the entire run was as follows: $\mathrm{U}^{235}, 869$; $\mathrm{U}^{238}, 98 ; \mathrm{Mg}, 346$; and $\mathrm{Zr}, 236$.

\section{EQUIPMENT PERFORMANCE}

The over-all performance of the loop during the in-pile run was very satisfactory. There were no failures or interruptions in loop operation which compromised the results obtained from the experi-

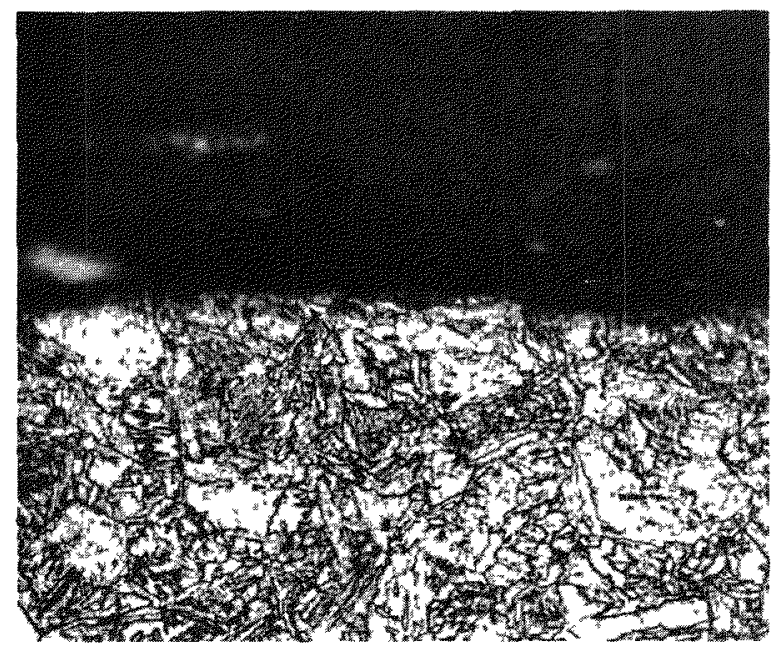

Figure 47. Heat-affected zone of longitudinal weld of specimen No. $487,2 \frac{1 / 4}{2} \mathrm{Cr}-1 \% \mathrm{Mo}, 100 \times$

ment. All the loop components performed to specification with the exception of the sampler. Of the two sampler failures, the first was due to mechanical failure. Wear in the vicinity of a positioning pin caused misalignment of the sample cup receiving piston and resulted in damage to the cups. Repairs were made during a shutdown and the sampler again performed satisfactorily. The cause of the second failure is not known but may have been operator error. At the point in the sampling procedure where the pressure in the sampler body is made equal to the loop pressure and the ball valve isolating the sampler from the loop is opened, the sampler's high liquid level alarm sounded and the loop was dumped automatically. A release of fission product gases was detected on the room air monitors. The sampler isolating valve was closed and the loop secured. Examination of the sampler indicated the presence of $\mathrm{Bi}$ in the pistons. A consideration of the possible reasons for this occurrence led to the conclusion that the sampler pressure was lower than the loop pressure at the time the isolating valve was opened. This situation could occur if the operator failed to open the necessary valves, or if a solenoid valve in the line failed to open. Less likely possibilities considered were momentary plugging of the sampler discharge line and air-lifting of $\mathrm{Bi}$ into the sampler by a bubble. In any case, the failure was not attributed to malfunction of the sampler itself and should not restrict consideration of the unit 


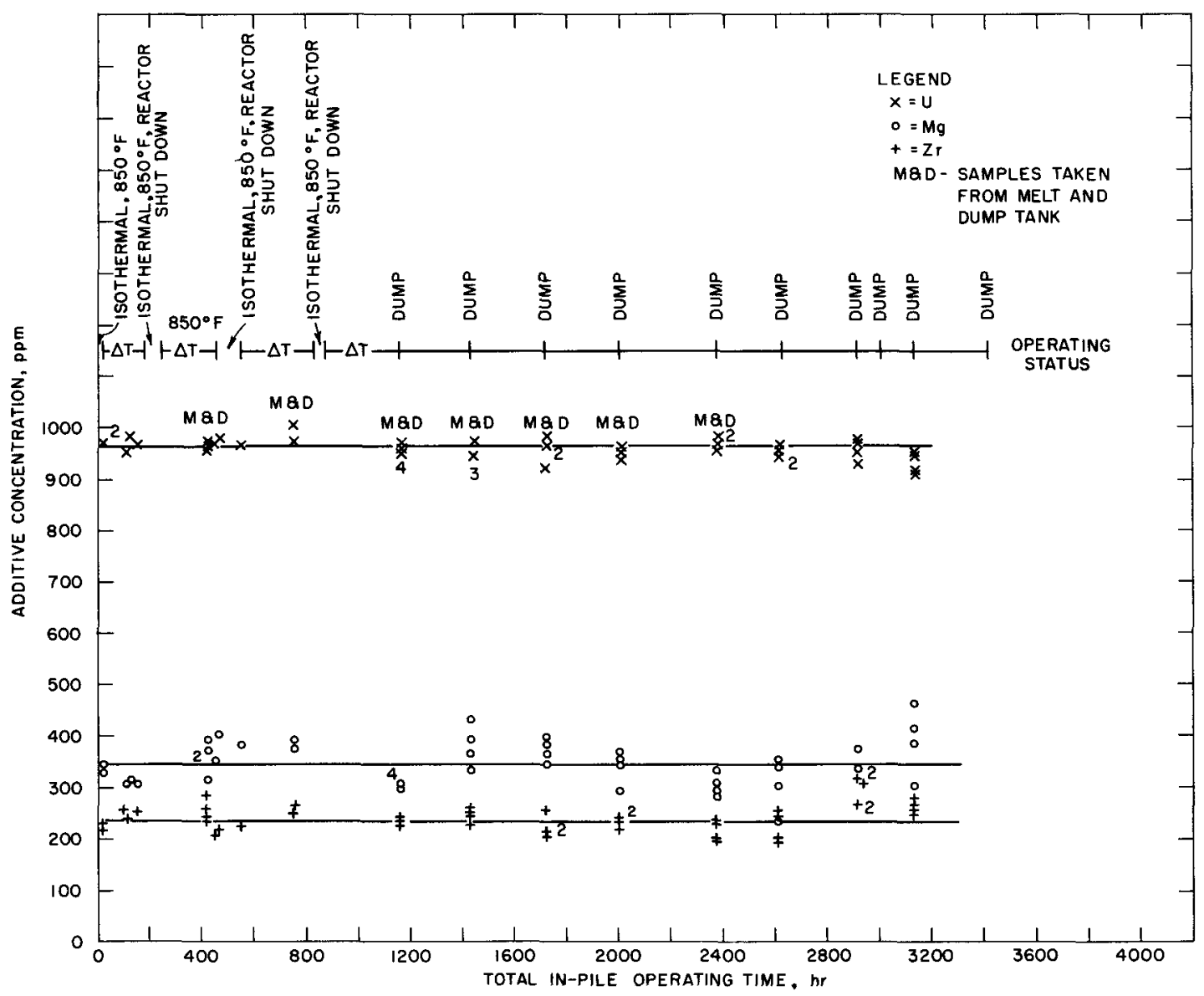

Figure 48. Additive concentrations during in-pile operation.

for similar applications. Since the in-pile run was well established, it was considered wise to avoid a prolonged shutdown for replacement of the sampler. For the remainder of the run, sampling was accomplished by dumping the loop during reactor shutdowns and sampling the charge while it was in the dump tank.

As was noted, the loop enclosure and exhaust system did not prevent the escape of active gases from the in-line sampler. The sampler enclosure was mounted on top of the main enclosure and was connected to it at its lower end. Apparently the contaminated $\mathrm{He}$ from the sampler rose to the top of the enclosure and was able to override the slight negative pressure in the box and escape.

An air-lock on the dump-tank sampling and charge port was originally considered adequate double containment. In actual use, this was not always the case. A glove box tied into the loop en- closure system would have been useful to supplement the air-lock operation.

There were no indications of radiation damage to any of the materials used in the loop. Activity levels were highest in the pump cell, but even here the dose was calculated to be slightly below those normally considered serious from the standpoint of radiation damage. No inspection was made of the pump cell or the pump itself.

\section{FLUX MEASUREMENT}

Four methods were provided for the measurement of the flux "seen" by the in-pile test pieces: (1) analysis of the U-Bi charge for fission products, (2) analysis for Po formed by activation of the $\mathrm{Bi}$, (3) the measurement of fission heat, and (4) the use of foils attached to the outside of the tube bundle. The latter method did not produce results, 
Table 4

Flux Measurements

\begin{tabular}{lcc}
\hline Method & $\begin{array}{c}\text { Average flux, } \\
\text { neutrons } / \mathrm{cm}^{2} \text {-sec }\end{array}$ & $\begin{array}{c}\text { Flux at test section, } \\
\text { neutrons } / \mathrm{cm}^{2} \text {-sec }\end{array}$ \\
\hline $\mathrm{Zr}^{95}$ analysis & $1.4 \times 10^{12}$ & $2.9 \times 10^{12}$ \\
$\mathrm{Ce}^{144}$ analysis & $2.6 \times 10^{12}$ & $5.5 \times 10^{12}$ \\
$\mathrm{Po}^{210}$ analysis & $1.1 \times 10^{12}$ & $2.3 \times 10^{12}$ \\
Heat balance & $3.2 \times 10^{12}$ & $6.7 \times 10^{12}$ \\
\hline
\end{tabular}

since the foils could not be removed from the inpile section containment at the completion of the experiment.

The average flux seen by the U-Bi in the in-pile test section was found to be $4.4 \times 10^{12}$ neutrons/ $\mathrm{cm}^{2}$-sec. The actual values ranged from 2.9 to 6.7 $\times 10^{12}$ neutrons $/ \mathrm{cm}^{2}$-sec. These results are summarized in Table 4. The average flux seen by the entire in-pile section was $2.1 \times 10^{12}$ neutrons $/ \mathrm{cm}^{2}$ sec.

During the experiment, the pile power varied from 17 to $20 \mathrm{Mw}$. An average value of $18.5 \mathrm{Mw}$ was used for the determination of the flux in the $\mathrm{Bi}$.

The fission density at the test section was found to be $5.5 \times 10^{10}$ fissions $/ \mathrm{cm}^{3}$-sec.

\section{Conclusions}

\section{RESULTS OF METALLOGRAPHIC EXAMINATION}

The results of the metallographic examination indicate that corrosion and/or erosion of the graphite and metal specimens was essentially nil. This gratifying observation must be qualified, however, because the metal specimens were not completely wetted. In view of the very limited wetting, it is impossible to predict the long-term behavior of such a system. Experience in corrosiontesting such systems suggests that the lack of wetting was due to two factors, the temperature and duration of the test. The results obtained in the test, however, demonstrate that the in-pile and out-of-pile behavior are very similar. It would appear that fission fragment recoils have not contributed materially to either wetting or corrosion. The results obtained suggest that even greater care should have been taken in the preparation of the corrosion test samples, so that extremely small amounts of attack could be detected. It should be pointed out that the test conditions were selected to simulate expected operating conditions for the proposed Liquid Metal Fuel Reactor Experiment. The results of this test demonstrate that corrosion and mass transfer probably would not have been a source of failure. Had the program continued, test conditions would have been made more severe (i.e., a higher hot leg temperature and an increased temperature differential). Out-of-pile tests had shown that, at a $\Delta T$ of $125^{\circ} \mathrm{C}$ and an upper $\mathcal{T}$ of $550^{\circ} \mathrm{C}$, wetting was readily obtained in $3000 \mathrm{hr}$ on both carbon steel and the low chrome steels; further, although some mass transfer and corrosion occurred in the low chrome systems, the attack on carbon steel was practically nil. Under these test conditions it might have been possible to demonstrate a fission fragment recoil effect.

\section{LOOP PERFORMANCE}

The over-all performance of the loop during the in-pile run was excellent. The major components for handling the $\mathrm{Bi}$ charge, such as the pump, valves, cooler, etc., performed satisfactorily and showed no degeneration in performance. Auxiliary equipment presented some difficulties, but none that compromised the experimental results. As described earlier, the sampler presented the most serious difficulties, with one mechanical and one either mechanical or operator failure. The incidents emphasize a design requirement for inpile loops, that is, component design should stress simplicity in connection with mechanical and operating functions, and the component should receive severe testing to reveal the weak points in the design. More attention to the enclosure and shielding problem would have proved helpful, particularly where piping and support structure arrangements were in conflict with enclosure and shielding needs. The tendency in planning was to defer enclosure and shielding work until arrangements for the process piping had been completed. Gas-line runs were located in positions difficult to shield.

\section{HANDLING OF Po IN Bi SYSTEMS}

Po contamination proved to be a simple problem. Apparently its association with the $\mathrm{Bi}$ limited the travel of alpha contamination. It is possible that a $\mathrm{Bi}$ leak, exposing the material to hot piping 
in an air atmosphere, might result in oxidation and powdering. An occurrence of this sort might result in a more serious Po hazard.

\section{Acknowledgments}

The services of many people are required to conduct an experiment as involved as the one described in this report. Each division of the Nuclear Engineering Department contributed to the development of the Radiation Loop in some way.

The authors wish to express their appreciation to the following individuals, who were closely associated with the experiment or made special contributions at various times during the course of the experiment: P.G. Russell and S.E. Knight, representing the Babcock \& Wilcox Co.; G. Hrabak, J. Davis, L. Nicolosi, M. Montag, R. Boehm, E. Thompson, J. Hare, R. Jones, J. Eichacker, P. Buhl, and M. Schuster of the Metal- lurgy Division; D. Huszagh, A. Oltmann, G. Roeser, A. Kokinelis, W. Lewis, R. Richter, C. Tierney, and F. Kaiser of the Engineering Division; T. Auerbach and N. Corngold, representing the Reactor Physics Division; and H. Finston and his Radiochemical Analysis Group.

The assistance in all phases of the project work by personnel of the Reactor and Health Physics Divisions also requires special mention. The efforts of J.J. Floyd, R.P. Reeve, L. Phillips, and A. Humm were particularly helpful.

\section{References}

1. A.E. Roswell, R.A. Meyer, and G.C. Hrabak, High temperature remotely operated pipe thickness gauge, Trans. Am. Nuclear Soc. 1, No. 1, 46 (1958).

2. D.W. Huszagh, Heat balance flowmeter for molten bismuth, Nucleones 17, No. 3, 114-15 (1959).

3. C.J Raseman, H. Susskind, and C.H. Waide, $L M F R$ 13. Liquid Metal Fuel Reactor In-Pile Fuel Processing Loop (Loop B), BNL 403 (T-88), Jan 1957. 